Supporting Information for:

\title{
Synthesis and metabolism of BTN3A1 ligands: studies on diene modifications to the
}

\section{phosphoantigen scaffold}

Nyema M. Harmon, ${ }^{1}$ Michael M. Poe,${ }^{2}$ Xueting Huang, ${ }^{2}$ Rohit Singh, ${ }^{2}$ Benjamin J. Foust, ${ }^{1}$ ChiaHung Christine Hsiao, ${ }^{2}$ David F. Wiemer, ${ }^{1,3}$ and Andrew J. Wiemer, ${ }^{2 *}$

${ }^{1}$ Department of Chemistry, University of Iowa, Iowa City, Iowa 52242-1294, United States

${ }^{2}$ Department of Pharmaceutical Sciences, University of Connecticut, Storrs, CT 06269-3092, United States

${ }^{3}$ Department of Pharmacology, University of Iowa, Iowa City, Iowa 52242-1109, United States

${ }^{4}$ Institute for Systems Genomics, University of Connecticut, Storrs, CT 06269-3092, United

States

E-mail: andrew.wiemer@uconn.edu 


\section{SUPPLEMENTAL TABLE OF CONTENTS}

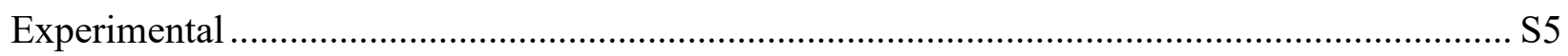

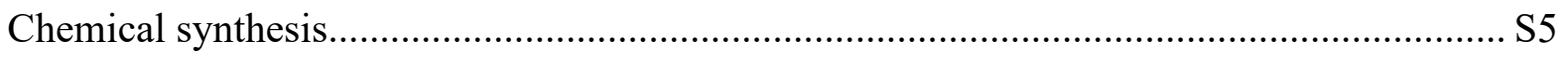

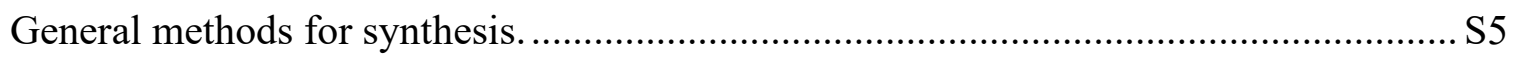

Dimethyl (2-hydroxy-4-methylpent-3-en-1-yl) phosphonate (6)................................... S5

Dimethyl (E)-(4-methylpenta-1,3-dien-1-yl) phosphonate (7) ………………….......... S6

(E)-((Methoxy(4-methylpenta-1,3-dien-1-yl)phosphoryl)oxy)methyl pivalate (8) and

(E)-(((4-methylpenta-1,3-dien-1-yl)phosphoryl) bis(oxy)) bis(methylene) bis(2,2-

dimethylpropanoate) (9)............................................................................................ S7

$((((1 E, 3 E)-5-(A c e t y l o x y)-4-m e t h y l p e n t a-1,3-d i e n-1-y l))((((2,2-$

dimethylpropanoyl)oxy) methoxy))phosphoryl)oxy)methyl 2,2-dimethylpropanoate

(13).

(2E,4E)-5-(Diethoxyphosphoryl)-2-methylpenta-2,4-dien-1-yl acetate (14) and diethyl ((1E,3E)-5-hydroxy-4-methylpenta-1,3-dien-1-yl) phosphonate (15)...

((1E,3E)-5-Hydroxy-4-methylpenta-1,3-dien-1-yl) phosphonic acid (16) ...................... S9

Diphenyl ((1E)-4-methylpenta-1,3-dien-1-yl) phosphonate (20) ................................. S10

Methyl (2S) 2-((((1E)-4-methylpenta-1,3-dien-1-yl) (phenoxy) phosphoryl) amino)

propanoate (21)

((((1E)-4-Methylpenta-1,3-dien-1-yl)(phenoxy)phosphoryl)oxy)methyl-2,2-

dimethylpropanoate (24) ....................................................................................... S12

Sodium (E)-(4-methylpenta-1,3-dien-1-yl) phosphonate (25)...................................... S13

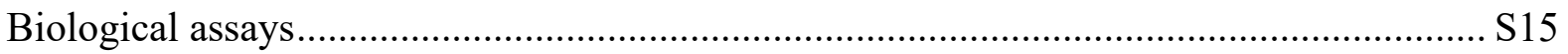

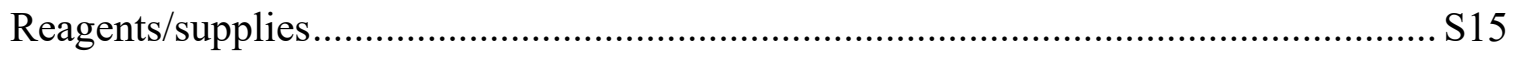

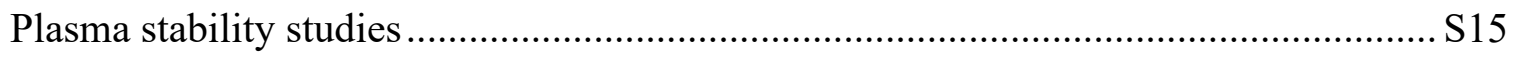

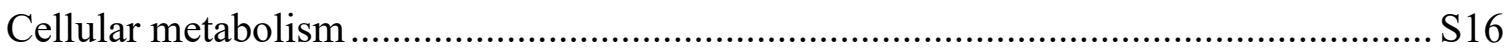

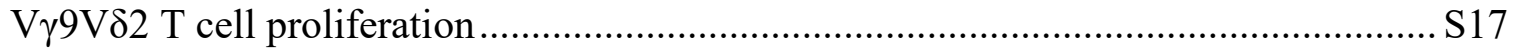

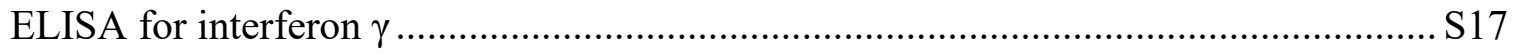

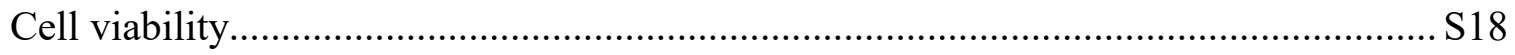




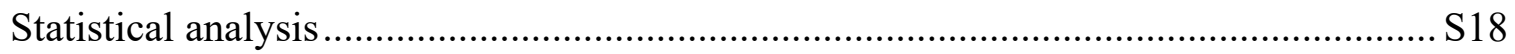

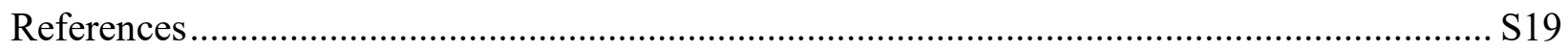

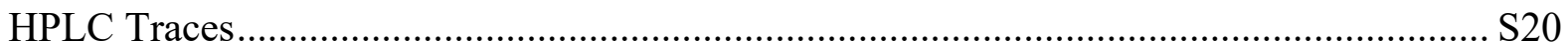

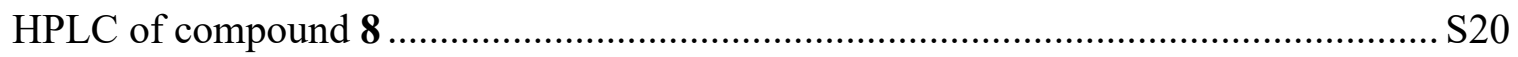

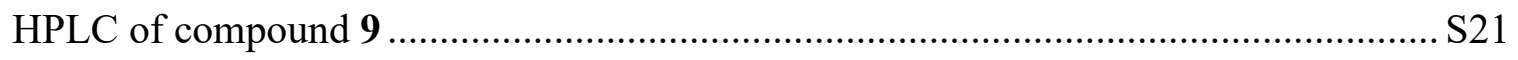

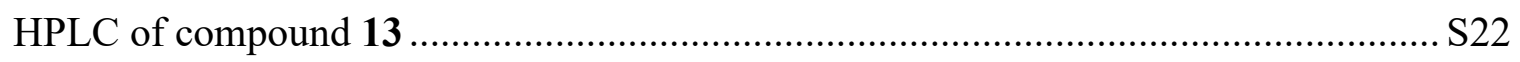

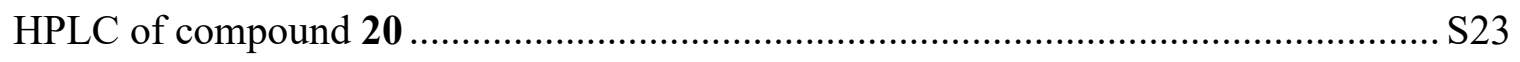

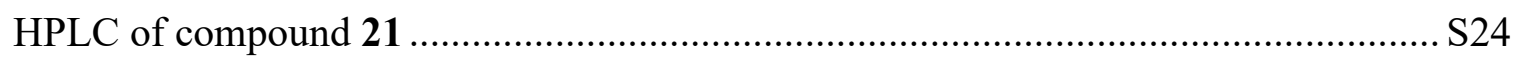

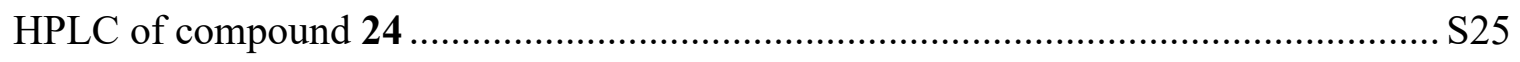

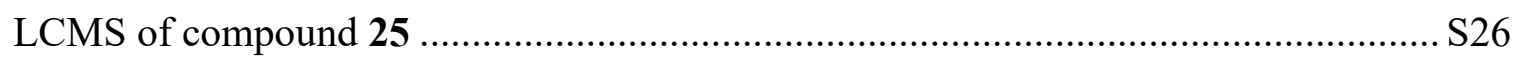

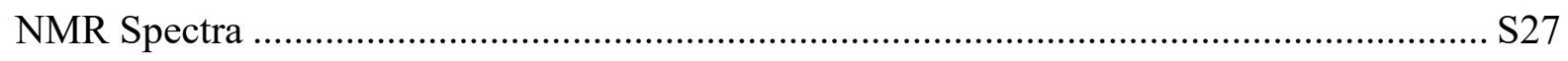

${ }^{1} \mathrm{H}$ NMR spectrum of compound $8(500 \mathrm{MHz})$....................................................... S27

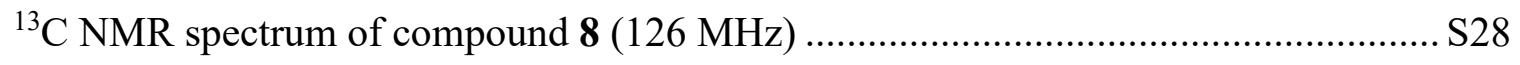

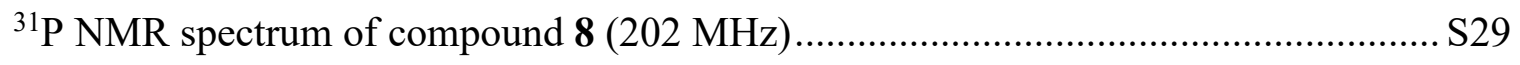

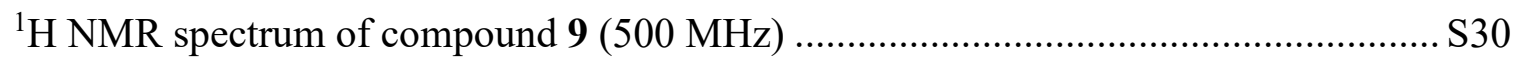

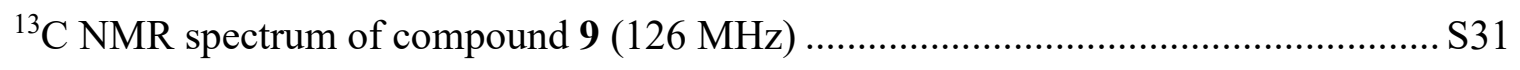

${ }^{31} \mathrm{P}$ NMR spectrum of compound 9 (202 MHz) ......................................................... S32

${ }^{1} \mathrm{H}$ NMR spectrum of compound 13 (500 MHz) ………........................................... S33

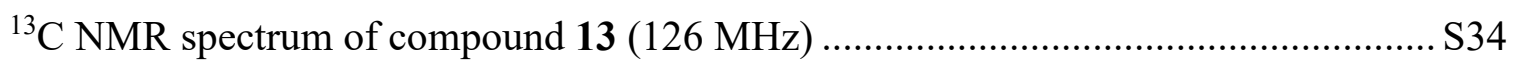

${ }^{31} \mathrm{P}$ NMR spectrum of compound 13 (162 MHz) ………………………………....... S35

${ }^{1} \mathrm{H}$ NMR spectrum of compound $\mathbf{1 6}(400 \mathrm{MHz})$.................................................... S36

${ }^{31} \mathrm{P}$ NMR spectrum of compound 16 (162 MHz) ...................................................... S37

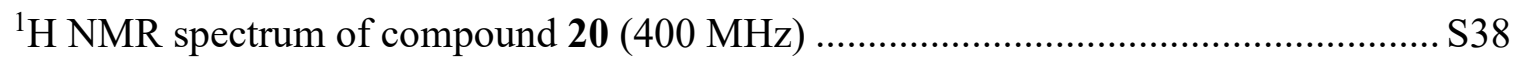

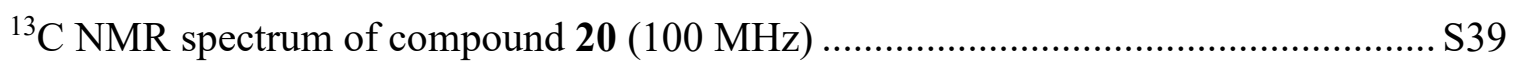

${ }^{31} \mathrm{P}$ NMR spectrum of compound 20 (162 MHz) ...................................................... S40 
${ }^{1} \mathrm{H}$ NMR spectrum of compound 21 (400 MHz) ................................................. S41

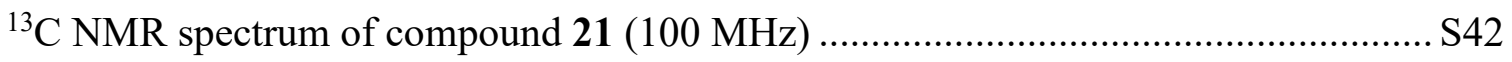

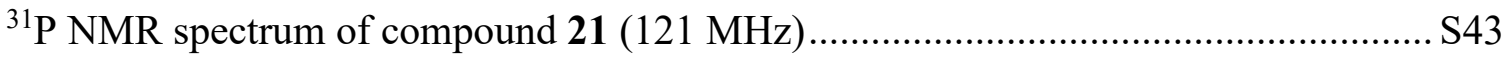

${ }^{1} \mathrm{H}$ NMR spectrum of compound $24(300 \mathrm{MHz})$.................................................. S44

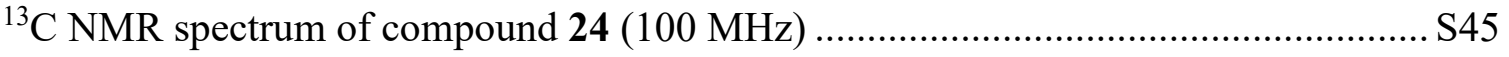

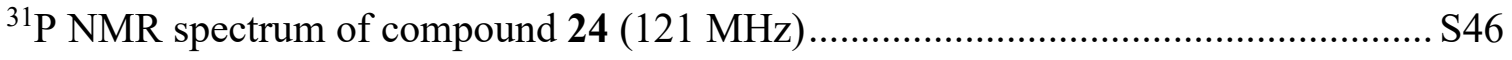

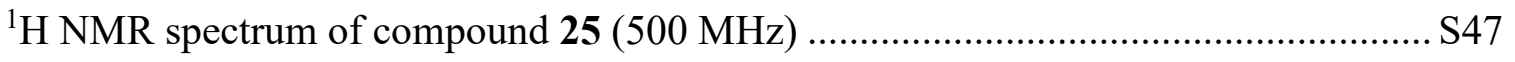

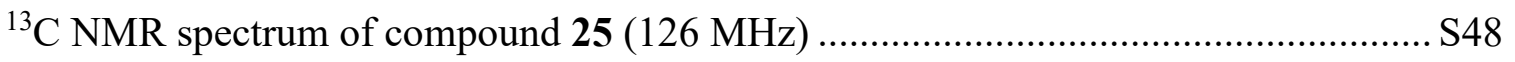

${ }^{31} \mathrm{P}$ NMR spectrum of compound 25 (202 MHz) ................................................ S49 


\section{Experimental}

\section{Chemical synthesis}

General methods for synthesis. Acetonitrile and dichloromethane were distilled from calcium hydride prior to use. Tetrahydrofuran (THF) was distilled from sodium metal immediately prior to use. Sodium iodide was dried overnight in an oven and triethylamine was dried over molecular sieves. All other reagents and solvents were purchased from commercial sources and used without further purification. Flame-dried glassware under a positive pressure of nitrogen or argon was utilized for all reactions in non-aqueous solvents and these reactions were conducted with a magnetic stir bar. For TLC analyses, pre-coated silica polyester-backed plates $(200 \mu \mathrm{M}$ thickness, UV254 indicator) were visualized under both short wave UV light (254 nm) and by $p$-anisaldehyde stain (93\% absolute ethanol, 3.5\% $18 \mathrm{M}$ sulfuric acid, 1\% acetic acid, 2.5\% $p$-anisaldehyde) or phosphomolybdic acid stain (10\% in ethanol). Silica gel (60Á, technical grade) was used for flash column chromatography. Compound purity (>95\%) was verified by HPLC on an Agilent 1120 infinity LC solvent delivery system with a variable wavelength UV detector or a Waters Synapt G2-Si with a q-TOF mass spectrometer. The NMR spectra were obtained at $300-500 \mathrm{MHz}$ for ${ }^{1} \mathrm{H}$, 100-126 MHz for ${ }^{13} \mathrm{C}$, and 121-202 $\mathrm{MHz}$ for ${ }^{31} \mathrm{P}$ in $\mathrm{CDCl}_{3}$ with $\left(\mathrm{CH}_{3}\right)_{4} \mathrm{Si}\left({ }^{1} \mathrm{H}, 0.00 \mathrm{ppm}\right)$ or $\mathrm{CDCl}_{3}$ itself $\left({ }^{1} \mathrm{H}, 7.26 ;{ }^{13} \mathrm{C}, 77.0 \mathrm{ppm}\right)$ as the internal standards. High-resolution mass spectrometry (HRMS) data were obtained by GC-TOF or q-TOF-LCMS for biologically tested compounds.

\section{Dimethyl (2-hydroxy-4-methylpent-3-en-1-yl) phosphonate (6). A solution of} diisopropylamine $(1.07 \mathrm{~mL}, 7.66 \mathrm{mmol})$ in THF $(6 \mathrm{~mL})$ and was stirred and cooled to $-78^{\circ} \mathrm{C}$ using a dry ice bath. $n$-Butyllithium $(3.06 \mathrm{~mL}, 7.66 \mathrm{mmol})$ was added dropwise and the solution was allowed to stir for $10 \mathrm{~min}$. Dimethyl methylphosphonate $(\mathbf{5}, 0.87 \mathrm{~mL}, 8.06 \mathrm{mmol})$ was added 
dropwise and the reaction mixture was allowed to stir for $15 \mathrm{~min}$. After 3-methyl-2-butenal ( 0.70 $\mathrm{mL}, 7.25 \mathrm{mmol}$ ) was added, the solution was stirred for $2 \mathrm{~h}$ or until starting material was consumed as indicated by TLC (silica gel). The dry ice bath was removed, and the reaction mixture was allowed to warm to $-20{ }^{\circ} \mathrm{C}$. The reaction was quenched by addition of saturated $\mathrm{NaHCO}_{3}$, and diluted with saturated $\mathrm{NH}_{4} \mathrm{Cl}$. After the organic materials were extracted with ethyl acetate $(3 \times 50$ $\mathrm{mL})$, the combined organic extracts were washed with brine, dried $\left(\mathrm{Na}_{2} \mathrm{SO}_{4}\right)$, and concentrated under vacuum. The residual oil was purified by flash chromatography with ethyl acetate:hexanes (80:20) to provide pure alcohol 6 as a colorless oil (972 mg, 64\%): ${ }^{1} \mathrm{H}$ NMR $\left(500 \mathrm{MHz}, \mathrm{CDCl}_{3}\right) \delta$ $5.28(\mathrm{~d}, \mathrm{~J}=8.5 \mathrm{~Hz}, 1 \mathrm{H}), 4.82(\mathrm{q}, \mathrm{J}=8.9 \mathrm{~Hz}, 1 \mathrm{H}), 3.82\left(\mathrm{~d}, J_{\mathrm{HP}}=4.8 \mathrm{~Hz}, 3 \mathrm{H}\right), 3.80\left(\mathrm{~d}, J_{\mathrm{HP}}=5.0 \mathrm{~Hz}\right.$, 3H), 3.03 (br s, 1H), $2.14-1.95$ (m, 2H), 1.77 (s, 3H), 1.75 (s, 3H); ${ }^{13} \mathrm{C}$ NMR (126 MHz, $\left.\mathrm{CDCl}_{3}\right)$ $\delta 135.6,126.9(\mathrm{~d}, \mathrm{JCP}=16.2 \mathrm{~Hz}), 63.7\left(\mathrm{~d}, J_{\mathrm{CP}}=4.1 \mathrm{~Hz}\right), 52.5\left(\mathrm{~d}, J_{\mathrm{CP}}=6.3 \mathrm{~Hz}\right), 52.4\left(\mathrm{~d}, J_{\mathrm{CP}}=6.6\right.$ $\mathrm{Hz}), 33.2\left(\mathrm{~d}, J_{\mathrm{CP}}=136.0 \mathrm{~Hz}\right), 25.7,18.2 ;{ }^{31} \mathrm{P} \mathrm{NMR}\left(202 \mathrm{MHz}, \mathrm{CDCl}_{3}\right) \delta 32.2$.

Dimethyl (E)-(4-methylpenta-1,3-dien-1-yl) phosphonate (7). After alcohol 6 (0.63 g, 3.026 mmol) was dissolved in THF ( $5 \mathrm{~mL})$, sulfuric acid (6 M, $1.01 \mathrm{~mL}, 6.05 \mathrm{mmol})$ was added dropwise and then the reaction was heated to reflux and allowed to stir for $30 \mathrm{~min}$. The solution was then cooled to $0{ }^{\circ} \mathrm{C}$ using an ice bath, was diluted with water, and was quenched by addition of saturated $\mathrm{NaHCO}_{3}$. After extraction with ethyl acetate, the organic extracts were combined, washed with brine, dried $\left(\mathrm{Na}_{2} \mathrm{SO}_{4}\right)$, and concentrated under vacuum. The resulting oil was purified by flash column chromatography with ethyl acetate in hexanes (5\% to $20 \%$ gradient) to provide the diene 7 as a colorless oil (58 mg, 10\%): ${ }^{1} \mathrm{H}$ NMR (500 MHz, $\left.\mathrm{CDCl}_{3}\right) \delta 7.40$ (ddd, $J=21.0,16.6,11.2$ Hz, 1H), 5.99 (d, $J=11.2 \mathrm{~Hz}, 1 \mathrm{H}), 5.51(\mathrm{dd}, J=20.3,16.7 \mathrm{~Hz}, 1 \mathrm{H}), 3.75(\mathrm{~s}, 3 \mathrm{H}), 3.73(\mathrm{~s}, 3 \mathrm{H})$, $1.91(\mathrm{~s}, 3 \mathrm{H}), 1.89(\mathrm{~s}, 3 \mathrm{H}) ;{ }^{31} \mathrm{P} \mathrm{NMR}\left(202 \mathrm{MHz}, \mathrm{CDCl}_{3}\right) \delta 23.6$. 
(E)-((Methoxy(4-methylpenta-1,3-dien-1-yl)phosphoryl)oxy)methyl pivalate (8) and (E)-(((4methylpenta-1,3-dien-1-yl)phosphoryl) ～bis(oxy)) ～bis(methylene) ～bis(2,2dimethylpropanoate) (9). Diene 7 (100 mg, $0.526 \mathrm{mmol}$ ) was stirred in $\mathrm{H}_{3} \mathrm{CCN}$ under argon. Sodium iodide $(276 \mathrm{mg}, 1.84 \mathrm{mmol})$ was added in one portion, followed by POM-Cl (0.264 mL, $1.84 \mathrm{mmol}$ ) and the reaction mixture was heated at reflux and stirred overnight. The reaction then was allowed to cool to RT, diluted with water, and extracted with ethyl acetate. The organic fractions were combined, washed with brine, dried $\left(\mathrm{Na}_{2} \mathrm{SO}_{4}\right)$, and concentrated under vacuum. The residual oil was purified by flash column chromatography (silica gel) to isolate both the mono- $(\mathbf{8}$, $62 \mathrm{mg}, 41 \%)$ and di-protected $(\mathbf{9}, 37 \mathrm{mg}, 18 \%)$ dienes as colorless oils. Compound $\mathbf{8}$ was racemic at phosphorus. For compound 8: ${ }^{1} \mathrm{H}$ NMR $\left(500 \mathrm{MHz}, \mathrm{CDCl}_{3}\right) \delta 7.41(\mathrm{ddd}, J=21.7,16.7,11.2 \mathrm{~Hz}$, 1H), $5.97(\mathrm{~d}, J=11.3 \mathrm{~Hz}, 1 \mathrm{H}), 5.78-5.64(\mathrm{~m}, 2 \mathrm{H}), 5.55(\mathrm{dd}, J=21.1,16.7 \mathrm{~Hz}, 1 \mathrm{H}), 3.76\left(\mathrm{~d}, J_{H P}\right.$ $=11.4 \mathrm{~Hz}, 3 \mathrm{H}), 1.91(\mathrm{~s}, 3 \mathrm{H}), 1.89(\mathrm{~s}, 3 \mathrm{H}), 1.24(\mathrm{~s}, 9 \mathrm{H}) ;{ }^{13} \mathrm{C} \mathrm{NMR}\left(126 \mathrm{MHz}, \mathrm{CDCl}_{3}\right) \delta 177.0$, $146.4,146.0\left(\mathrm{~d}, J_{C P}=6.9 \mathrm{~Hz}\right), 124.6\left(\mathrm{~d}, J_{C P}=27.5 \mathrm{~Hz}\right), 112.4\left(\mathrm{~d}, J_{C P}=195.7 \mathrm{~Hz}\right), 81.8\left(\mathrm{~d}, J_{C P}=\right.$ $4.9 \mathrm{~Hz}), 52.1\left(\mathrm{~d}, J_{C P}=6.1 \mathrm{~Hz}\right), 38.7,26.9(3 \mathrm{C}), 26.4,18.9 ;{ }^{31} \mathrm{P} \mathrm{NMR}\left(202 \mathrm{MHz}, \mathrm{CDCl}_{3}\right) \delta 22.1$. HRMS (AccuTOF-LCMS) $m / z$ calculated for $\mathrm{C}_{13} \mathrm{H}_{23} \mathrm{NaO}_{5} \mathrm{P}(\mathrm{M}+\mathrm{Na})^{+} 313.1181$, found 313.1169 . For compound 9: ${ }^{1} \mathrm{H}$ NMR $\left(500 \mathrm{MHz}, \mathrm{CDCl}_{3}\right) \delta 7.41(\mathrm{ddd}, J=22.4,16.6,11.3 \mathrm{~Hz}, 1 \mathrm{H}), 5.96(\mathrm{~d}$, $J=11.3 \mathrm{~Hz}, 1 \mathrm{H}), 5.77-5.64(\mathrm{~m}, 4 \mathrm{H}), 5.57(\mathrm{dd}, J=21.9,16.6 \mathrm{~Hz}, 1 \mathrm{H}), 1.90(\mathrm{~s}, 3 \mathrm{H}), 1.89(\mathrm{~s}, 3 \mathrm{H})$, $1.24(\mathrm{~s}, 18 \mathrm{H}) ;{ }^{13} \mathrm{C} \mathrm{NMR}\left(126 \mathrm{MHz}, \mathrm{CDCl}_{3}\right) \delta 176.8(2 \mathrm{C}), 147.0,146.2\left(\mathrm{~d}, J_{C P}=7.1 \mathrm{~Hz}\right), 124.5(\mathrm{~d}$, $\left.J_{C P}=28.1 \mathrm{~Hz}\right), 112.4\left(\mathrm{~d}, J_{C P}=194.4 \mathrm{~Hz}\right), 81.5\left(\mathrm{~d}, J_{C P}=5.2 \mathrm{~Hz}, 2 \mathrm{C}\right), 38.7(2 \mathrm{C}), 26.8(6 \mathrm{C}), 26.4$, 19.0; ${ }^{31} \mathrm{P}$ NMR (202 MHz, $\left.\mathrm{CDCl}_{3}\right) \delta$ 20.8. HRMS (AccuTOF-LCMS) $\mathrm{m} / z$ calculated for $\mathrm{C}_{18} \mathrm{H}_{31} \mathrm{NaO}_{7} \mathrm{P}(\mathrm{M}+\mathrm{H})^{+}$413.1705, found 413.1682. 
methoxy))phosphoryl)oxy)methyl 2,2-dimethylpropanoate (13). To a flask equipped with a stir bar, alcohol $10(2.4 \mathrm{~g}, 16.6 \mathrm{mmol})^{1}$ and bis(acetoxy)iodobenzene (BAIB, $\left.6.4 \mathrm{~g}, 20 \mathrm{mmol}\right)$ were added to a solution of $\mathrm{CH}_{3} \mathrm{CN}(160 \mathrm{~mL})$ and a $\mathrm{pH} 7.00$ buffer $(0.05 \mathrm{M}$ sodium and potassium phosphate buffer, $8.3 \mathrm{~mL}$ ). After 2,2,6,6-tetramethylpiperidin-1-yl)oxidanyl (TEMPO, $0.26 \mathrm{~g}, 1.7$ mmol) was added, the solution was left to stir at RT until completion. Volatiles were removed via evaporative distillation. The unpurified aldehyde residue 11 was dissolved in ethyl acetate and brine and the aqueous layer was washed 3 times with ethyl acetate. The organic fractions were combined and dried $\left(\mathrm{Na}_{2} \mathrm{SO}_{4}\right)$ before removal of volatiles in vacuo overnight. To a flame-dried flask equipped with a stir bar, $\mathrm{NaH}(60 \%$ in dispersion oil, $41 \mathrm{mg}, 1.72 \mathrm{mmol})$, was added to a solution of THF $(1.4 \mathrm{~mL})$ and cooled to $-78{ }^{\circ} \mathrm{C}$ before the addition of TMMBP $(0.22 \mathrm{~mL}, 1.07$ mmol). After $1 \mathrm{~h}$ of stirring, the aldehyde $\mathbf{1 1}(150 \mathrm{mg}, 1.06 \mathrm{mmol})$ was added dropwise to the basic solution and the reaction was left to warm slowly to RT overnight. The reaction mixture was quenched by addition of brine and ethyl acetate. The aqueous layer was washed with ethyl acetate ( 3 times), the extracts were combined and dried $\left(\mathrm{Na}_{2} \mathrm{SO}_{4}\right)$ before removal of volatiles under vacuum overnight. To a flame-dried flask equipped with a stir bar, phosphonate $12(100 \mathrm{mg}, 0.36$ mmol), NaI (120 mg, $0.8 \mathrm{mmol})$, and POM-Cl $(0.12 \mathrm{~mL}, 0.8 \mathrm{mmol})$ were suspended in $\mathrm{CH}_{3} \mathrm{CN}$ $(0.5 \mathrm{~mL})$. The mixture was stirred at reflux for $24 \mathrm{~h}$ before removal of volatiles. Purification was done with an automatic column (ISCO) with a solvent gradient from $0 \%$ diethyl ether in hexanes to $100 \%$ diethyl ether which provided the bis-POM phosphonate $\mathbf{1 3}$ as a yellow oil (72 $\mathrm{mg}, 14 \%$ ): ${ }^{1} \mathrm{H}$ NMR $\left(500 \mathrm{MHz}, \mathrm{CDCl}_{3}\right) \delta 7.14(\mathrm{~m}, 1 \mathrm{H}), 5.92\left(\mathrm{t}, J_{\mathrm{HP}}=6.5 \mathrm{~Hz}, 1 \mathrm{H}\right), 5.75\left(\mathrm{dd}, J_{\mathrm{HP}}=19.2,17.3\right.$ $\mathrm{Hz}, 1 \mathrm{H}), 5.67\left(\mathrm{dd}, J_{\mathrm{HP}}=4.6,3.9 \mathrm{~Hz}, 4 \mathrm{H}\right), 4.74\left(\mathrm{~d}, J_{\mathrm{HP}}=6.6 \mathrm{~Hz}, 2 \mathrm{H}\right), 2.07(\mathrm{~s}, 3 \mathrm{H}), 1.81(\mathrm{~s}, 3 \mathrm{H})$, $1.21(\mathrm{~s}, 18 \mathrm{H}) ;{ }^{13} \mathrm{C} \mathrm{NMR}\left(126 \mathrm{MHz}, \mathrm{CDCl}_{3}\right) \delta 176.8(2 \mathrm{C}), 170.7,152.7\left(\mathrm{~d}, J_{\mathrm{CP}}=7.0 \mathrm{~Hz}\right), 136.0(\mathrm{~d}$, 
$\left.J_{\mathrm{CP}}=25.0 \mathrm{~Hz}\right), 133.9,113.1\left(\mathrm{~d}, J_{\mathrm{HP}}=195 \mathrm{~Hz}\right), 81.4\left(\mathrm{~d}, J_{\mathrm{HP}}=5.4 \mathrm{~Hz}, 2 \mathrm{C}\right), 60.9\left(\mathrm{~d}, J_{\mathrm{HP}}=1.8 \mathrm{~Hz}\right)$, 38.7 (2C), 26.8 (6C), 20.8, $12.2 ;{ }^{31} \mathrm{P}$ NMR (162 MHz, $\mathrm{CDCl}_{3}$ ) $\delta 20.8$. HRMS (TOF MS EI) $\mathrm{m} / \mathrm{z}$ calculated for $\mathrm{C}_{20} \mathrm{H}_{33} \mathrm{O} 9 \mathrm{PNa}(\mathrm{M}+\mathrm{Na})^{+} 471.1760$, found 471.1761 .

(2E,4E)-5-(Diethoxyphosphoryl)-2-methylpenta-2,4-dien-1-yl acetate (14) and diethyl ((1E,3E)-5-hydroxy-4-methylpenta-1,3-dien-1-yl) phosphonate (15). TEMBP (3.52 g, 12.2 mmol) was introduced dropwise to a suspension of $35 \% \mathrm{KH}(1.39 \mathrm{~g}, 12.2 \mathrm{mmol})$ in THF (50 mL) at $0{ }^{\circ} \mathrm{C}$ and allowed to react for $30 \mathrm{~min}$. The resulting anion was transferred via cannula to a solution of aldehyde $11(1.45 \mathrm{~g}, 10.2 \mathrm{mmol})$ in THF $(50 \mathrm{~mL})$ at $0{ }^{\circ} \mathrm{C}$ and allowed to react for $6 \mathrm{~h}$. The reaction was quenched by slow addition of a $1 \mathrm{M}$ solution of acetic acid in diethyl ether and then concentrated under vacuum. The resulting material was purified via column chromatography (silica, ethyl acetate) to give the phosphonate 14 in 57\% yield (1.60 g) along with the deprotected alcohol 15. For acetate 14: ${ }^{1} \mathrm{H}$ NMR $\left(400 \mathrm{MHz}, \mathrm{CDCl}_{3}\right) \delta 7.35-7.22(\mathrm{~m}, 1 \mathrm{H}), 6.07(\mathrm{~d}, J=10.8$ Hz, 1H), $5.62(\mathrm{dd}, J=18.4,17.6 \mathrm{~Hz}, 1 \mathrm{H}), 4.47(\mathrm{~s}, 2 \mathrm{H}), 4.04-4.00(\mathrm{~m}, 4 \mathrm{H}), 2.02(\mathrm{br} \mathrm{s}, 3 \mathrm{H}), 1.80$

(br s, 3H), 1.26-1.19 (m, 6H). For alcohol 15: ${ }^{1} \mathrm{H}$ NMR (400 MHz, $\left.\mathrm{CDCl}_{3}\right) \delta$ 7.44-7.31 (m, 1H), $6.26(\mathrm{~d}, J=11.2 \mathrm{~Hz}, 1 \mathrm{H}), 5.61(\mathrm{dd}, J=20.4,16.4 \mathrm{~Hz}, 1 \mathrm{H}), 4.11(\mathrm{~s}, 2 \mathrm{H}), 4.07\left(\mathrm{dq}, J_{\mathrm{PH}}=8.0 \mathrm{~Hz}, J\right.$ $=7.0 \mathrm{~Hz}, 4 \mathrm{H}), 1.84(\mathrm{~s}, 3 \mathrm{H}), 1.33(\mathrm{t}, J=7.0 \mathrm{~Hz}, 6 \mathrm{H}) ;{ }^{13} \mathrm{C} \mathrm{NMR}\left(100 \mathrm{MHz}, \mathrm{CDCl}_{3}\right) \delta 147.5,144.6$ $\left(\mathrm{d}, J_{\mathrm{PC}}=6.7 \mathrm{~Hz}\right), 120.2\left(\mathrm{~d}, J_{\mathrm{PC}}=26.9 \mathrm{~Hz}\right), 115.2\left(\mathrm{~d}, J_{\mathrm{PC}}=191.8 \mathrm{~Hz}\right), 66.8,61.7\left(\mathrm{~d} J_{\mathrm{PC}}=6.0 \mathrm{~Hz}\right.$, 2C), $16.3\left(\mathrm{~d}, J_{\mathrm{PC}}=6.5 \mathrm{~Hz}, 2 \mathrm{C}\right), 14.5 ;{ }^{31} \mathrm{P} \mathrm{NMR}\left(121 \mathrm{MHz}, \mathrm{CDCl}_{3}\right) \delta+20.2$.

((1E,3E)-5-Hydroxy-4-methylpenta-1,3-dien-1-yl) phosphonic acid (16). Through a procedure analogous to a literature report on hydrolysis of a diethyl phosphonate bearing an allylic alcohol, ${ }^{2}$ $\operatorname{TMSBr}(0.17 \mathrm{~mL})$ was added dropwise to a solution of diethyl phosphonate 15 (53 mg, 0.225 
mmol $)$ in $\mathrm{CH}_{2} \mathrm{Cl}_{2}(2 \mathrm{~mL})$ at RT and the solution was stirred for $\sim 20 \mathrm{~h}$. After the volatile materials were removed in vacuo, methanol was added $(20 \mathrm{~mL})$ and the resulting solution was stirred for 3 h. Concentration under vacuum gave the desired phosphonic acid $\mathbf{1 6}$ and final treatment with $\mathrm{NaOH}$ afforded the corresponding sodium salt: ${ }^{1} \mathrm{H}$ NMR $\left(400 \mathrm{MHz}, \mathrm{D}_{2} \mathrm{O}\right) \delta 7.03$ (ddd, $J=19.7$, $16.8,10.9 \mathrm{~Hz}, 1 \mathrm{H}), 6.65(\mathrm{~d}, J=10.9 \mathrm{~Hz}, 1 \mathrm{H}), 5.79(\mathrm{dd}, J=18.4,17.1 \mathrm{~Hz}, 1 \mathrm{H}), 3.99(\mathrm{~s}, 2 \mathrm{H}), 1.75$ $(\mathrm{s}, 3 \mathrm{H}) ;{ }^{31} \mathrm{P} \mathrm{NMR}\left(121 \mathrm{MHz}, \mathrm{CDCl}_{3}\right) \delta+13.5$. HRMS (AccuTOF-LCMS) $m / z$ calculated for $\mathrm{C}_{6} \mathrm{H}_{10} \mathrm{O}_{4} \mathrm{P}(\mathrm{M})^{-}, 177.0317$, found, 177.0319.

Diphenyl ((1E)-4-methylpenta-1,3-dien-1-yl) phosphonate (20). $\mathrm{NaH}$ (60\% in dispersion oil, $571 \mathrm{mg}, 24.0 \mathrm{mmol})$ was added to THF $(16 \mathrm{~mL})$ in a flame-dried flask and the reaction mixture was cooled to $-78{ }^{\circ} \mathrm{C}$ before the addition of TEMBP $(3.3 \mathrm{~mL}, 13.1 \mathrm{mmol})$. After $1 \mathrm{~h}$ of stirring, prenal $(\mathbf{1 7}, 1.15 \mathrm{~mL}, 11.9 \mathrm{mmol})$ was added dropwise to the basic solution and the reaction was left to warm slowly to RT overnight. The reaction mixture was quenched by addition of saturated $\mathrm{NH}_{4} \mathrm{Cl}$ and ethyl acetate. The aqueous layer was washed with ethyl acetate (3 times), the organic extracts were combined and dried $\left(\mathrm{Na}_{2} \mathrm{SO}_{4}\right)$ before removal of volatiles overnight in vacuo. Phosphonate diene 18 (522 mg, $2.4 \mathrm{mmol})$ was transferred in $\mathrm{CH}_{2} \mathrm{Cl}_{2}(11 \mathrm{~mL})$ to a flame-dried flask, then TMSBr $(3.1 \mathrm{~mL}, 23.4 \mathrm{mmol})$ was then added slowly to the solution. After $24 \mathrm{~h}$ volatiles were removed in vacuo. The resulting residue was dissolved in $\mathrm{CH}_{2} \mathrm{Cl}_{2}(11 \mathrm{~mL})$ and cooled to 0 ${ }^{\circ} \mathrm{C}$ before addition of oxalyl chloride $(0.62 \mathrm{~mL}, 7.2 \mathrm{mmol})$ and DMF (3 drops). After $20 \mathrm{~h}$ the volatiles were removed in vacuo leaving the dichloride 19. To another flame-dried flask containing phenol $(339 \mathrm{mg}, 3.6 \mathrm{mmol}), \mathrm{Et}_{3} \mathrm{~N}(0.67 \mathrm{~mL}, 4.8 \mathrm{mmol})$, and $\mathrm{CH}_{2} \mathrm{Cl}_{2}(7 \mathrm{~mL})$ at $-78{ }^{\circ} \mathrm{C}$, the dichloride 19 was transferred with $\mathrm{CH}_{2} \mathrm{Cl}_{2}(3 \mathrm{~mL})$ and the reaction was left to warm slowly to $\mathrm{RT}$ overnight. Purification was done with an automatic column (ISCO) with a solvent gradient of $0 \%$ 
to $50 \%$ acetone in diethyl ether which provided bis-phenyl phosphonate $\mathbf{2 0}$ as a white solid (231 $\mathrm{mg}, 26 \%) .{ }^{1} \mathrm{H}$ NMR $\left(400 \mathrm{MHz}, \mathrm{CDCl}_{3}\right) \delta 7.52\left(\mathrm{ddd}, J_{\mathrm{HP}}=11.35 .7,5.6 \mathrm{~Hz}, 1 \mathrm{H}\right), 6.36-6.16,(\mathrm{~m}$, $10 \mathrm{H}), 6.00\left(\mathrm{~d}, J_{\mathrm{HP}}=11.3 \mathrm{~Hz}, 1 \mathrm{H}\right), 5.73\left(\mathrm{dd}, J_{\mathrm{HP}}=22.0 \mathrm{~Hz}, 1 \mathrm{H}\right), 0.88(\mathrm{~s}, 6 \mathrm{H}) ;{ }^{13} \mathrm{C} \mathrm{NMR}(100$ $\left.\mathrm{MHz}, \mathrm{CDCl}_{3}\right) \delta 151.5,148.7\left(\mathrm{~d}, J_{\mathrm{CP}}=7.4 \mathrm{~Hz}, 2 \mathrm{C}\right), 130.8(4 \mathrm{C}), 126.0\left(\mathrm{~d}, J_{\mathrm{CP}}=1.2 \mathrm{~Hz}, 2 \mathrm{C}\right), 125.8$, $125.5,121.8\left(\mathrm{~d}, J_{\mathrm{CP}}=4.5 \mathrm{~Hz}, 4 \mathrm{C}\right), 112.9\left(\mathrm{~d}, J_{\mathrm{CP}}=196.5 \mathrm{~Hz}\right), 27.6\left(\mathrm{~d}, J_{\mathrm{CP}}=1.7 \mathrm{~Hz}\right), 20.1 ;{ }^{31} \mathrm{P}$ NMR $\left(162 \mathrm{MHz}, \mathrm{CDCl}_{3}\right) \delta$ 14.6. HRMS (TOF MS EI) $\mathrm{m} / z$ calculated for $\mathrm{C}_{18} \mathrm{H}_{20} \mathrm{O}_{3} \mathrm{P}(\mathrm{M}+\mathrm{H})^{+}$ 315.1150 , found 315.1138 .

\section{Methyl (2S) 2-((((1E)-4-methylpenta-1,3-dien-1-yl) (phenoxy) phosphoryl) amino)} propanoate (21). Phosphonate diene $18(1.52 \mathrm{~g}, 7.0 \mathrm{mmol})$ was dissolved in $\mathrm{CH}_{2} \mathrm{Cl}_{2}(35 \mathrm{~mL})$ and then transferred to a flame-dried flask. TMSBr $(9.0 \mathrm{~mL}, 70 \mathrm{mmol})$ was added slowly to the resulting solution. After $24 \mathrm{~h}$ the volatiles were removed in vacuo. The resulting residue was dissolved in $\mathrm{CH}_{2} \mathrm{Cl}_{2}(35 \mathrm{~mL})$ and cooled to $0{ }^{\circ} \mathrm{C}$ before the addition of oxalyl chloride $(1.82 \mathrm{~mL}$, $21 \mathrm{mmol}$ ) and DMF (5 drops). After $20 \mathrm{~h}$ the volatiles were removed in vacuo leaving the dichloride 19. To a second flame-dried flask containing phenol (600 mg, $6.3 \mathrm{mmol}), \mathrm{Et}_{3} \mathrm{~N}(2.0 \mathrm{~mL}$, $14 \mathrm{mmol})$, and $\mathrm{CH}_{2} \mathrm{Cl}_{2}(25 \mathrm{~mL})$ at $-78{ }^{\circ} \mathrm{C}$, the dichloride 19 was transferred with $\mathrm{CH}_{2} \mathrm{Cl}_{2}(10 \mathrm{~mL})$ and the reaction was left to warm slowly to RT over $3 \mathrm{~h}$. The volatiles were removed in vacuo. The resulting residue was dissolved in $\mathrm{CH}_{2} \mathrm{Cl}_{2}(10 \mathrm{~mL})$ and transferred to a solution of $\mathrm{L}$-alanine methyl ester hydrochloride $(1.95 \mathrm{~g}, 14 \mathrm{mmol})$ and $\mathrm{Et}_{3} \mathrm{~N}(2.0 \mathrm{~mL}, 14 \mathrm{mmol})$ in $\mathrm{CH}_{2} \mathrm{Cl}_{2}(25 \mathrm{~mL})$ at $-78{ }^{\circ} \mathrm{C}$. Purification was achieved through flash column chromatography on a gradient $(100 \%$ diethyl ether to $5 \%$ methanol in diethyl ether) to yield phosphonamidate $\mathbf{2 1}$ as a brown oil and the expected mixture of diastereomers (881 mg, 39\%). ${ }^{1} \mathrm{H} \mathrm{NMR}\left(400 \mathrm{MHz}, \mathrm{CDCl}_{3}\right) \delta$ 7.47-7.35 (m, 1H), 7.32-7.28 (m, 2H), 7.23-7.20 (m, 2H), 7.14-7.10 (m, 1H), $5.93\left(\mathrm{~d}, J_{\mathrm{HP}}=9.9 \mathrm{~Hz}, 1 \mathrm{H}\right), 5.77-$ $5.61(\mathrm{~m}, 1 \mathrm{H}), 4.09-3.99(\mathrm{~m}, 1 \mathrm{H}), 3.69-3.66(\mathrm{~m}, 3 \mathrm{H}), 3.63-3.47(\mathrm{~m}, 1 \mathrm{H}), 1.87-1.85(\mathrm{~m}, 6 \mathrm{H}), 1.34$ 
$\left(2 \mathrm{~d}, J_{\mathrm{HP}}=1.5 \mathrm{~Hz}, 3 \mathrm{H}\right) ;{ }^{13} \mathrm{C} \mathrm{NMR}\left(100 \mathrm{MHz}, \mathrm{CDCl}_{3}\right) \delta 174.4-174.3\left(2 \mathrm{~d}, J_{\mathrm{CP}}=6.2,5.9 \mathrm{~Hz}, 1 \mathrm{C}\right)$, $150.7-150.5\left(2 \mathrm{~d}, J_{\mathrm{CP}}=7.5,6.9 \mathrm{~Hz}, 1 \mathrm{C}\right), 145.8-144.9\left(2 \mathrm{~d}, J_{\mathrm{CP}}=6.3,3.6 \mathrm{~Hz}, 1 \mathrm{C}\right), 129.6\left(\mathrm{~d}, J_{\mathrm{CP}}=\right.$ $4.3 \mathrm{~Hz}, 2 \mathrm{C}), 124.9-124.7(2 \mathrm{~s}, 1 \mathrm{C}), 124.5(2 \mathrm{C}), 120.6\left(2 \mathrm{~d}, J_{\mathrm{CP}}=9.0,4.8 \mathrm{~Hz}, 1 \mathrm{C}\right), 115.1\left(\mathrm{dd}, J_{\mathrm{CP}}=\right.$ 181.9, 8.1 Hz, 1C), 65.9, $52.4\left(\mathrm{~d}, J_{\mathrm{CP}}=4.0 \mathrm{~Hz}, 1 \mathrm{C}\right), 49.5\left(\mathrm{~d}, J_{\mathrm{CP}}=10.1 \mathrm{~Hz}, 1 \mathrm{C}\right), 26.4\left(\mathrm{~d}, J_{\mathrm{CP}}=1.0\right.$ $\mathrm{Hz}, 1 \mathrm{C}), 21.3\left(2 \mathrm{~d}, J_{\mathrm{CP}}=18.2,4.5 \mathrm{~Hz}, 1 \mathrm{C}\right), 18.9 ;{ }^{31} \mathrm{P} \mathrm{NMR}\left(121 \mathrm{MHz}, \mathrm{CDCl}_{3}\right) \delta 21.1,20.6$. HRMS (TOF MS EI) $m / z$ calculated for $\mathrm{C}_{16} \mathrm{H}_{23} \mathrm{NO}_{4} \mathrm{P}(\mathrm{M}+\mathrm{H})^{+} 324.1365$, found 324.1350 .

\section{((((1E)-4-Methylpenta-1,3-dien-1-yl)(phenoxy)phosphoryl)oxy)methyl-2,2-}

dimethylpropanoate (24). To a flame-dried flask containing diethyl phosphonate $\mathbf{1 8}$ (2.6 g, 11.9 mmol) and $\mathrm{CH}_{2} \mathrm{Cl}_{2}(30 \mathrm{~mL})$ at $0{ }^{\circ} \mathrm{C}$, DMF (3 drops) and oxalyl chloride $(3.1 \mathrm{~mL}, 36 \mathrm{mmol})$ were added and the reaction was allowed to stir and warm slowly to RT over $20 \mathrm{~h}$ before removal of volatiles in vacuo. To the resulting brown residue, phenol (1.12 $\mathrm{g}, 11.9 \mathrm{mmol})$ was added before sequential addition of THF $(30 \mathrm{~mL})$ and then trimethylamine $(3.32 \mathrm{~mL}, 23.8 \mathrm{mmol})$. The reaction mixture was stirred at $\mathrm{RT}$ for $1 \mathrm{~h}$ before removal of volatiles in vacuo. The resulting brown residue was dissolved in $\mathrm{CH}_{2} \mathrm{Cl}_{2}(15 \mathrm{~mL})$ followed by the slow addition of TMSBr $(3.1 \mathrm{~mL}, 23.8 \mathrm{mmol})$ and the solution was left to stir at RT for $24 \mathrm{~h}$ before removal of volatiles in vacuo. The brown residue was dissolved in a solution of $\mathrm{CH}_{3} \mathrm{CN} /$ water $(4: 1,5 \mathrm{~mL})$ which was immediately removed under vacuum. To the resulting residue, silver carbonate $(8.53 \mathrm{~g}, 31 \mathrm{mmol})$ was added. The mixture was suspended in $\mathrm{CH}_{3} \mathrm{CN}(80 \mathrm{~mL})$ before addition of $\mathrm{POM}-\mathrm{Cl}(4.3 \mathrm{~mL}, 30 \mathrm{mmol})$ and subsequent reflux overnight. After the volatiles were removed in vacuo, purification via flash column chromatography $(33 \%$ hexanes in $[2 \%$ trimethylamine in ethyl acetate $]$ to $100 \%[2 \%$ trimethylamine in ethyl acetate]) gave the racemic mixed aryl/acyloxyalkyl phosphonate diene $\mathbf{2 4}$ as a yellow oil (1.77 g, 42\%). High pressure chromatography (HPLC) trace was used with $100 \%$ 
HPLC grade $\mathrm{CH}_{3} \mathrm{CN}$ to access prodrug purity. ${ }^{1} \mathrm{H} \mathrm{NMR}\left(300 \mathrm{MHz}, \mathrm{CDCl}_{3}\right) \delta 7.48$ (ddd, $J=16.6$, 11.0, 10.8 Hz, 1H), $7.34\left(\mathrm{t}, J_{\mathrm{HP}}=7.9 \mathrm{~Hz}, 2 \mathrm{H}\right), 7.23\left(\mathrm{~d}, J_{\mathrm{HP}}=7.7 \mathrm{~Hz}, 2 \mathrm{H}\right), 7.18\left(\mathrm{t}, J_{\mathrm{HP}}=7.3 \mathrm{~Hz}\right.$, $1 \mathrm{H}), 5.97\left(\mathrm{~d}, J_{\mathrm{HP}}=11.2 \mathrm{~Hz}, 1 \mathrm{H}\right), 5.74(\mathrm{dd}, J=13.6,1.1 \mathrm{~Hz}, 2 \mathrm{H}), 5.66(\mathrm{dd}, J=22.0,16.7, \mathrm{~Hz}, 1 \mathrm{H})$, $1.89(\mathrm{~s}, 3 \mathrm{H}), 1.88(\mathrm{~s}, 3 \mathrm{H}), 1.20(\mathrm{~s}, 9 \mathrm{H}) ;{ }^{13} \mathrm{C} \mathrm{NMR}\left(100 \mathrm{MHz}, \mathrm{CDCl}_{3}\right) \delta 177.0,150.2\left(\mathrm{~d}, J_{\mathrm{CP}}=9.5\right.$ $\mathrm{Hz}), 147.1,146.8\left(\mathrm{~d}, J_{\mathrm{CP}}=6.9 \mathrm{~Hz}\right), 129.7(2 \mathrm{C}), 125.0,124.5\left(\mathrm{~d}, J_{\mathrm{CP}}=27.5 \mathrm{~Hz}\right), 120.7\left(\mathrm{~d}, J_{\mathrm{CP}}=\right.$ $4.4 \mathrm{~Hz}, 2 \mathrm{C}), 112.2\left(\mathrm{~d}, J_{\mathrm{CP}}=196.2 \mathrm{~Hz}\right), 81.8\left(\mathrm{~d}, J_{\mathrm{CP}}=5.9 \mathrm{~Hz}\right), 38.7,26.8(3 \mathrm{C}), 26.4\left(\mathrm{~d}, J_{\mathrm{CP}}=1.5\right.$ $\mathrm{Hz}), 19.0 ;{ }^{31} \mathrm{P}$ NMR $\left(121 \mathrm{MHz}, \mathrm{CDCl}_{3}\right) \delta$ 17.6. HRMS (TOF MS EI) $m / z$ calculated for $\mathrm{C}_{18} \mathrm{H}_{25} \mathrm{O} \mathrm{O}_{5} \mathrm{PNa}(\mathrm{M}+\mathrm{Na})^{+}$375.1337, found 375.1320.

Sodium (E)-(4-methylpenta-1,3-dien-1-yl) phosphonate (25). Compound 18 (174 mg, 0.80 mmol) was dissolved in $\mathrm{CH}_{2} \mathrm{Cl}_{2}$, and the mixture was cooled to $0{ }^{\circ} \mathrm{C}$ in an ice bath. Collidine $(0.425 \mathrm{ml}, 3.2 \mathrm{mmol})$ and $\mathrm{TMSBr}(0.419 \mathrm{ml}, 3.2 \mathrm{mmol})$ were added, and the reaction was allowed to stir overnight at RT. After the volatiles were removed, toluene was added and removed under vacuum, and this cycle was repeated three times providing a white solid. The solid was dissolved in aqueous $\mathrm{NaOH}(1.49 \mathrm{M}, 2.15 \mathrm{ml}, 3.2 \mathrm{mmol})$, and the reaction mixture was stirred overnight. The mixture was poured into an equal volume of acetone and cooled at $7^{\circ} \mathrm{C}$ for a period of $24 \mathrm{~h}$ to facilitate precipitation. Acetone and $\mathrm{H}_{2} \mathrm{O}$ were removed under vacuum, and the resulting solid was washed with acetone, dissolved in $\mathrm{H}_{2} \mathrm{O}$, and washed with diethyl ether and then with ethyl acetate. The aqueous phase was then concentrated under vacuum to provide the target salt in $91 \%$ yield (187 mg). ${ }^{1} \mathrm{H}$ NMR (500 MHz, CD $\left.3 \mathrm{OD}\right) \delta$ 7.15-7.05 (m, 1H), $5.90\left(\mathrm{~d}, J_{\mathrm{HP}}=11 \mathrm{~Hz}, 1 \mathrm{H}\right), 5.78$ $\left(\mathrm{t}, J_{\mathrm{HP}}=16.5 \mathrm{~Hz}, 1 \mathrm{H}\right), 1.84(\mathrm{~s}, 3 \mathrm{H}), 1.82(\mathrm{~s}, 3 \mathrm{H}) ;{ }^{13} \mathrm{C} \mathrm{NMR}\left(126 \mathrm{MHz}, \mathrm{CD}_{3} \mathrm{OD}\right) \delta 137.9,136.2(\mathrm{~d}$, $\left.J_{\mathrm{CP}}=5.1 \mathrm{~Hz}\right), 126.1\left(\mathrm{t}, J_{\mathrm{CP}}=26.9 \mathrm{~Hz}\right), 124.9,24.8,17.1 ;{ }^{31} \mathrm{P} \mathrm{NMR}\left(202 \mathrm{MHz}, \mathrm{CD}_{3} \mathrm{OD}\right) \delta 12.94$. HRMS (ES) $m / z$ calculated for $\mathrm{C}_{6} \mathrm{H}_{10} \mathrm{O}_{3} \mathrm{P}(\mathrm{M})^{-}$161.0373, found 161.0379. 


\section{Biological assays}

Reagents/supplies. These studies were performed with the supplies necessary for evaluating performance of the test compounds in plasma, K562 cells, and V $\gamma 9 \mathrm{~V} \delta 2 \mathrm{~T}$ cells by LC-MS, flow cytometry, ELISA, and cell viability assays. Human peripheral blood mononuclear cell (PBMCs) were isolated from buffy coat obtained from Research Blood Components (Boston, MA). K562 cells were from Sigma Aldrich. HMBPP was purchased from Echelon (Salt Lake City, UT). The BCA assay kit, FITC-conjugated anti- $\gamma \delta$-TCR (5A6.E91) antibody, BODIPY FL GDP bis(triethylammonium)salt, and pooled human plasma were purchased from Fisher (Waltham, MA). The phycoerythrin conjugated anti-CD3 (UCHT1) antibody and interferon $\gamma$ enzyme-linked immunosorbent assay kit were purchased from Biolegend (San Diego, CA). The CellQuanti-Blue Cell Viability Assay Kit was purchased from BioAssay Systems (Hayward, CA). The TCR $\gamma / \delta+T$ Cell Isolation Kit and interleukin 2 (IL-2) were from Miltenyi (Bergisch Gladbach, Germany).

Plasma stability studies. The stability of the novel prodrugs was determined by LC-MS following an incubation with human plasma. Pooled human plasma was diluted to $50 \%$ with tris buffered saline at $\mathrm{pH}$ 7.5. Test compounds were added at a final concentration of $100 \mu \mathrm{M}$ in a volume of $100 \mu \mathrm{L}$. Compounds were incubated for various times as indicated in the text, then extracted with $300 \mu \mathrm{L}$ of LCMS grade $\mathrm{CH}_{3} \mathrm{CN}$ and vigorous mixing. Insoluble debris was pelleted by centrifugation at $10,000 \mathrm{rcf}$ for $2 \mathrm{~min} .10 \mu \mathrm{L}$ of the extract was evaluated by LCMS with a Waters Synapt G2-Si Mass Spectrometer in positive mode using a gradient starting at $25 \% \mathrm{CH}_{3} \mathrm{CN}$ then increasing to $80 \% \mathrm{CH}_{3} \mathrm{CN}$ over 8 min. Masses corresponding to the molecular ion $[\mathrm{M}+\mathrm{H}]^{+}$, the sodium adduct $[\mathrm{M}+\mathrm{Na}]^{+}$, and the dimer $[2 \mathrm{M}+\mathrm{Na}]^{+}$were generally observed, though this data varied by compound. The calculated $\mathrm{m} / \mathrm{z}$ values of these forms were searched. The retention times 
for compounds were as follows: compound $\mathbf{3}, \mathrm{t}=5.47-5.53$; compound $\mathbf{8}, \mathrm{t}=5.53-5.54$; compound $\mathbf{9}, \mathrm{t}=6.90-6.91$; compound $\mathbf{1 3}, \mathrm{t}=6.29$; compound $\mathbf{2 0}, \mathrm{t}=6.58$; compound $\mathbf{2 1}, \mathrm{t}=5.12-5.13$. Integrated peak intensities of at least the 3 most prevalent ions identified for each compound were summed.

Cellular metabolism. The metabolism of the novel prodrugs was determined by LC-MS following an incubation with K562 cells. The K562 cells (5M cells in $500 \mu \mathrm{L}$ of T cell media) were treated for $1 \mathrm{~h}$ with $100 \mu \mathrm{M}$ of each test compound. The cells were pelleted by centrifugation ( $600 \mathrm{rcf}$ for $3 \mathrm{~min}$ ) and media was aspirated. The metabolites were extracted by addition of $200 \mu \mathrm{L}$ of extraction solvent (75\% LCMS grade $\left.\mathrm{CH}_{3} \mathrm{CN}, 25 \% 75 \mathrm{mM} \mathrm{NH}_{3} \mathrm{OH}\right)^{3}$ and vigorous mixing for 30 s. Insoluble debris was pelleted by centrifugation at $10,000 \mathrm{rcf}$ for $2 \mathrm{~min} .10 \mu \mathrm{L}$ of the extract was evaluated by LCMS with a Waters Synapt G2-Si Mass Spectrometer in negative mode using a C18 column and a gradient of $10 \mathrm{mM}$ triethylammonium acetate (A) and methanol/10 mM triethylammonium acetate $\mathrm{pH} 6(90 / 10, \mathrm{v} / \mathrm{v})(\mathrm{B}) .{ }^{4}$ The gradient started at $10 \% \mathrm{~B}$ then increased to $80 \% \mathrm{~B}$ over $4 \mathrm{~min}$ and held there for $2.5 \mathrm{~min}$ before re-equilibration.

Extracts were compared to authentic standards of C-HMBP and C-HMBPP. Mono-acid forms of the POM prodrugs were expected based on literature and the calculated $\mathrm{m} / \mathrm{z}$ values of these aldehyde and alcohol form metabolites were searched. To identify additional unknown metabolites, the LCMS traces from extracts of K562 cells treated with each compound were compared to untreated K562 cell extracts using Progenesis software (Waters) and ranked according to peak intensity and fold-increase in the treated versus untreated cells. The masses and retention times for identified compounds were as follows (free acid alcohol, $t_{\mathrm{R}}=1.47-1.55$; free acid aldehyde, $t_{\mathrm{R}}=1.37-1.57$; mono-POM alcohol, $t_{\mathrm{R}}=3.8-3.92 ;$ mono POM aldehyde, $t_{\mathrm{R}}=3.91-$ 
4.05; mono-naphthyl alcohol, $t_{\mathrm{R}}=4.09-4.19$; mono-naphthyl aldehyde, $\left.t_{\mathrm{R}}=4.19-4.29\right)$. At $\mathrm{pH} 7$ the phosphonate is expected to be mono-protonated and the mono-esters deprotonated such that all compounds detected carried a natural charge of -1 . For all compounds tested, masses corresponding to the molecular ion $[\mathrm{M}]^{-}$, were observed at the reported retention time.

V $\gamma 9 \mathrm{~V} \delta 2 \mathrm{~T}$ cell proliferation. The ability to stimulate $\mathrm{V} \gamma 9 \mathrm{~V} \delta 2 \mathrm{~T}$ cell proliferation was assessed by flow cytometry after PBMC stimulation with the test compounds. ${ }^{5-6}$ Human PBMCs were stimulated with various doses of test compounds between $1 \mathrm{nM}$ and $100 \mu \mathrm{M}$. Treatments with 100 $\mathrm{nM}$ of HMBPP and $100 \mathrm{nM}$ of $\mathbf{3}$ were used as positive controls. Negative controls contained cells with IL-2 and no test compounds. Cells were stimulated for 3 days, washed, and allowed to grow for 11 additional days, with fresh IL2 supplemented every 3 days. Cells were stained with antiCD3-PE and anti-pan-TCR- $\gamma \delta$-FITC and the number of double positive cells quantified by flow cytometry using FlowJo.

ELISA for interferon $\gamma$. The ability to stimulate cytokine production was quantified by ELISA after exposure of $\mathrm{V} \gamma 9 \mathrm{~V} \delta 2 \mathrm{~T}$ cells to compound-loaded $\mathrm{K} 562$ cells. Interferon $\gamma$ was measured using an ELISA kit according to manufacturer's directions. ${ }^{6-7} \mathrm{~K} 562$ cells were loaded with test compounds, washed twice, then mixed with $\mathrm{V} \gamma 9 \mathrm{~V} \delta 2 \mathrm{~T}$ cells that had been purified by negative selection. The compound exposure times were 4, 15, 60 and $240 \mathrm{~min}$. Each time point contained a dose response curve in which the range of concentrations used was determined by a pilot experiment for each compound. Each well contained a 3:1 effector: target ratio in $200 \mu \mathrm{L}$. After $20 \mathrm{~h}$ of co-culture in the absence of test compounds, the concentration of interferon $\gamma$ in the 
supernatant was determined. The maximum response was determined by the positive control of $\mathbf{3}$ at $1 \mu \mathrm{M}$ for $1 \mathrm{~h}$.

Cell viability. Cell viability was determined after compound treatment using a colorimetric assay for cell metabolic activity. Viability assays were performed using K562 cells with various concentrations of test compounds. K562 cells $\left(0.5 \times 10^{4}\right.$ cells in $100 \mu \mathrm{L}$ of RPMI media) were distributed into each well of a 96-well plate. The novel dienes were added for $72 \mathrm{~h}$, during the last $2 \mathrm{~h}$ the cell-QB reagent was added, following which signals were quantified with a fluorescence plate reader. Viable cells were expressed as a percentage of untreated control cells after subtraction of a media-only blank.

Fluorescence polarization. To assess binding of the ligands to BTN3A1, we used a previously developed fluorescence polarization assay according to the optimized conditions. ${ }^{8}$ Briefly, compounds were incubated with the BTN3A1 BFI construct $(10 \mu \mathrm{M})$ and the GDP-BODIPY probe $(750 \mathrm{nM})$ in $1 \mathrm{M}$ tris $\mathrm{pH} 7.5$ for 60 minutes and the polarization was detected at an emission/excitation wavelength of 535/485 nm (Perkin Elmer VICTOR X5).

Statistical analysis. In dose response data, $\mathrm{EC}_{50}$ values and $95 \%$ confidence intervals were determined using a four-parameter log agonist versus response model in GraphPad Prism. 


\section{References}

1. Harmon, N. M.; Huang, X.; Schladetsch, M. A.; Hsiao, C.-H. C.; Wiemer, A. J.; Wiemer, D. F., Potent double prodrug forms of synthetic phosphoantigens. Biorg. Med. Chem. 2020, 28 (19), 115666.

2. $\quad$ Sgraja, T.; Alphey, M. S.; Ghilagaber, S.; Marquez, R.; Robertson, M. N.; Hemmings, J. L.; Lauw, S.; Rohdich, F.; Bacher, A.; Eisenreich, W.; Illarionova, V.; Hunter, W. N., Characterization of Aquifex aeolicus 4-diphosphocytidyl-2C-methyl-d-erythritol kinase - ligand recognition in a template for antimicrobial drug discovery. FEBS J. 2008, 275 (11), 2779-94. 3. Tong, H. X.; Kuder, C. H.; Wasko, B. M.; Hohl, R. J., Quantitative determination of isopentenyl diphosphate in cultured mammalian cells. Anal. Biochem. 2013, 433 (1), 36-42. 4. Joachimiak, L.; Janczewski, L.; Ciekot, J.; Boratynski, J.; Blazewska, K., Applying the prodrug strategy to alpha-phosphonocarboxylate inhibitors of Rab GGTase - synthesis and stability studies. Organic \& Biomolecular Chemistry 2015, 13 (24), 6844-6856.

5. Hsiao, C. H.; Lin, X.; Barney, R. J.; Shippy, R. R.; Li, J.; Vinogradova, O.; Wiemer, D. F.; Wiemer, A. J., Synthesis of a phosphoantigen prodrug that potently activates Vgamma9Vdelta2 T-lymphocytes. Chem. Biol. 2014, 21 (8), 945-54.

6. $\quad$ Shippy, R. R.; Lin, X.; Agabiti, S. S.; Li, J.; Zangari, B. M.; Foust, B. J.; Poe, M. M.; Hsiao, C. C.; Vinogradova, O.; Wiemer, D. F.; Wiemer, A. J., Phosphinophosphonates and Their Tris-pivaloyloxymethyl Prodrugs Reveal a Negatively Cooperative Butyrophilin Activation Mechanism. J. Med. Chem. 2017, 60 (6), 2373-2382.

7. Kilcollins, A. M.; Li, J.; Hsiao, C. H.; Wiemer, A. J., HMBPP Analog Prodrugs Bypass Energy-Dependent Uptake To Promote Efficient BTN3A1-Mediated Malignant Cell Lysis by Vgamma9Vdelta2 T Lymphocyte Effectors. J. Immunol. 2016, 197 (2), 419-28.

8. $\quad$ Poe, M. M.; Agabiti, S. S.; Liu, C.; Li, V.; Teske, K. A.; Hsiao, C. C.; Wiemer, A. J., Probing the Ligand-Binding Pocket of BTN3A1. J. Med. Chem. 2019, 62 (14), 6814-6823. 


\section{HPLC Traces}

\section{HPLC of compound 8}

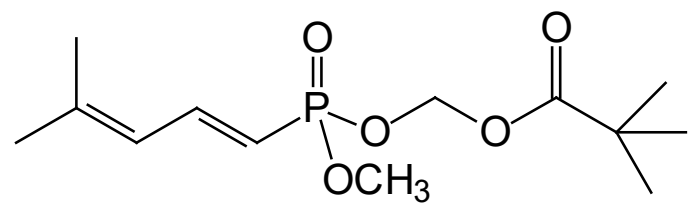

8

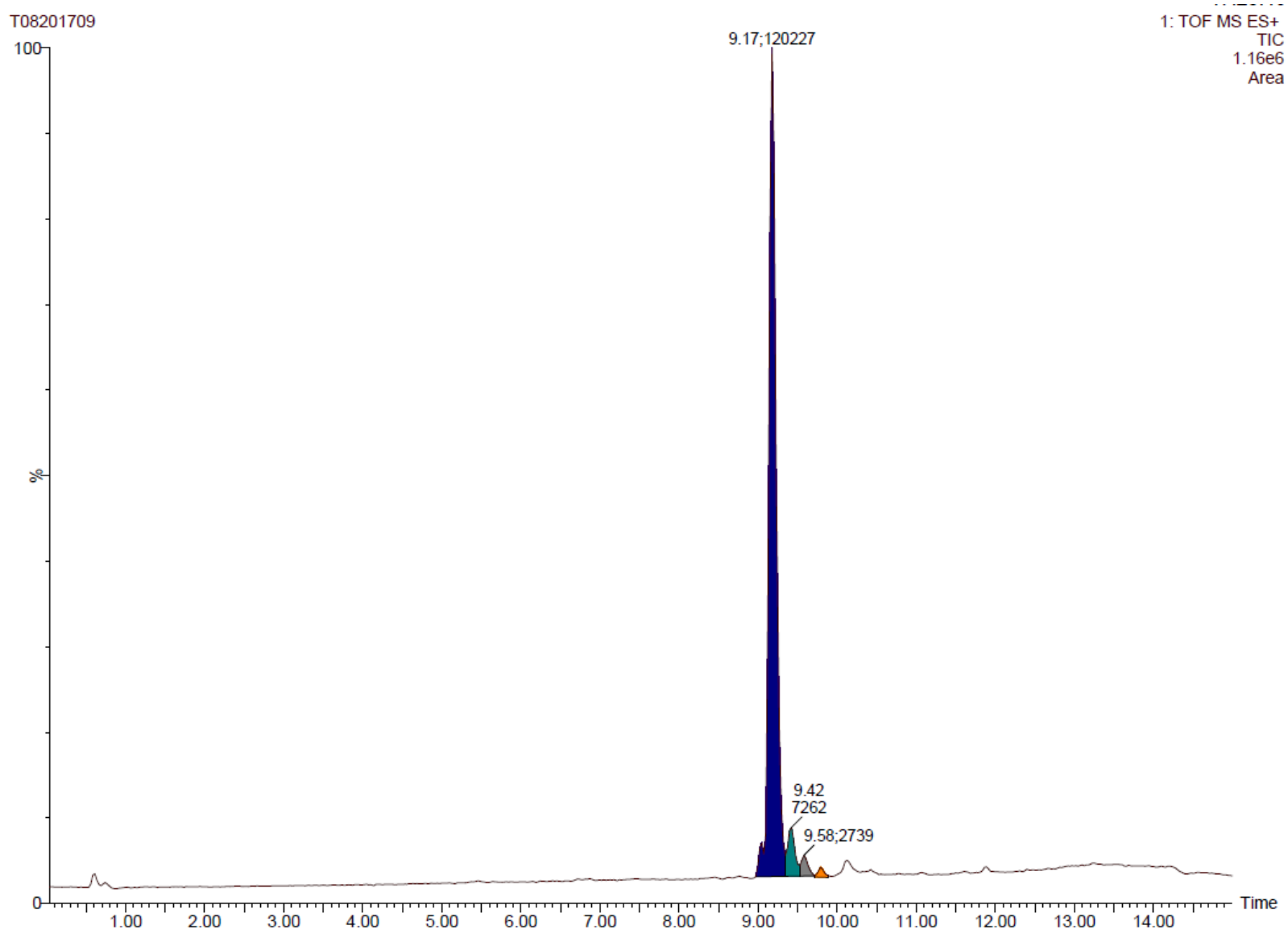




\section{HPLC of compound 9}

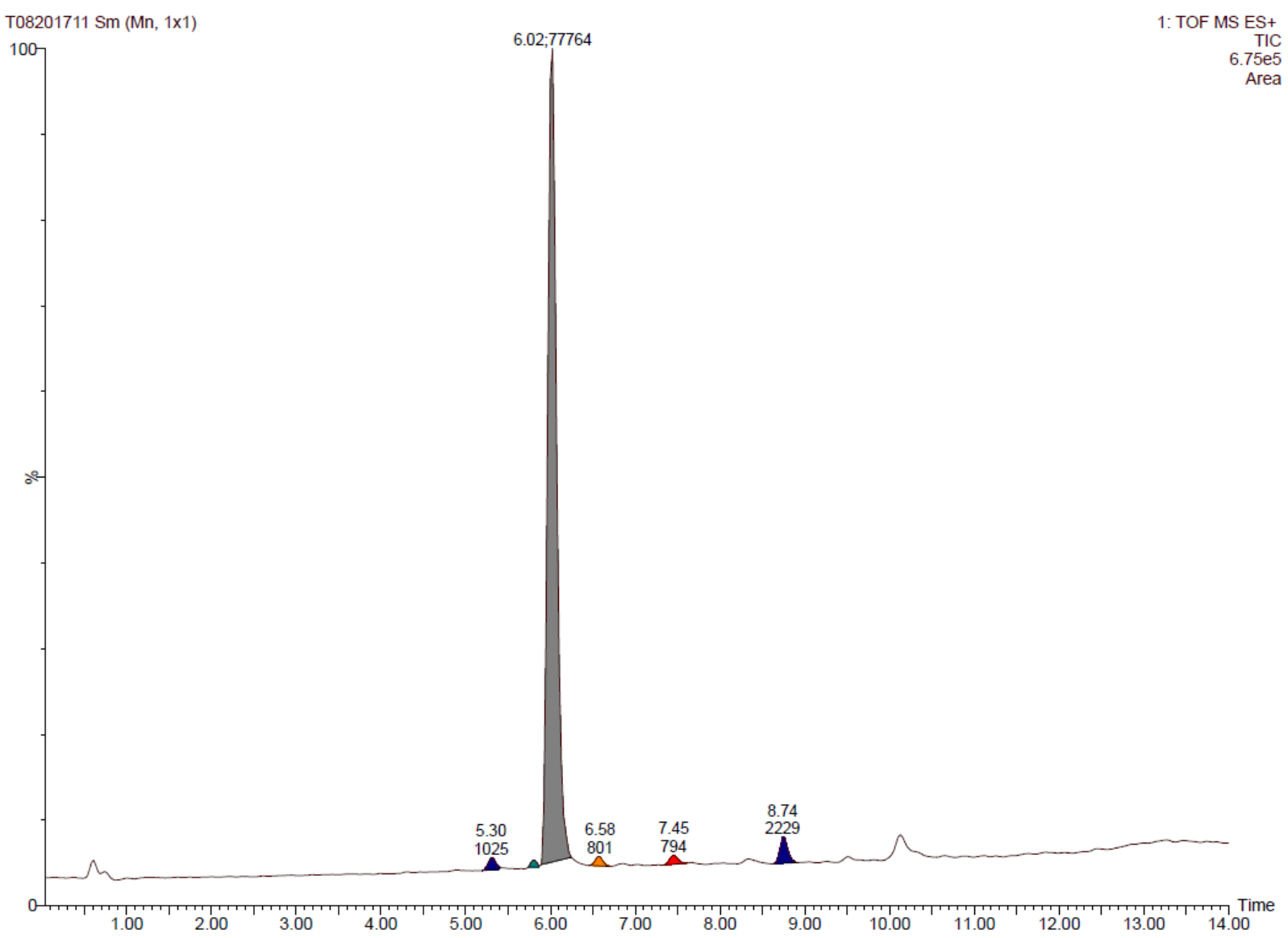




\section{HPLC of compound 13}

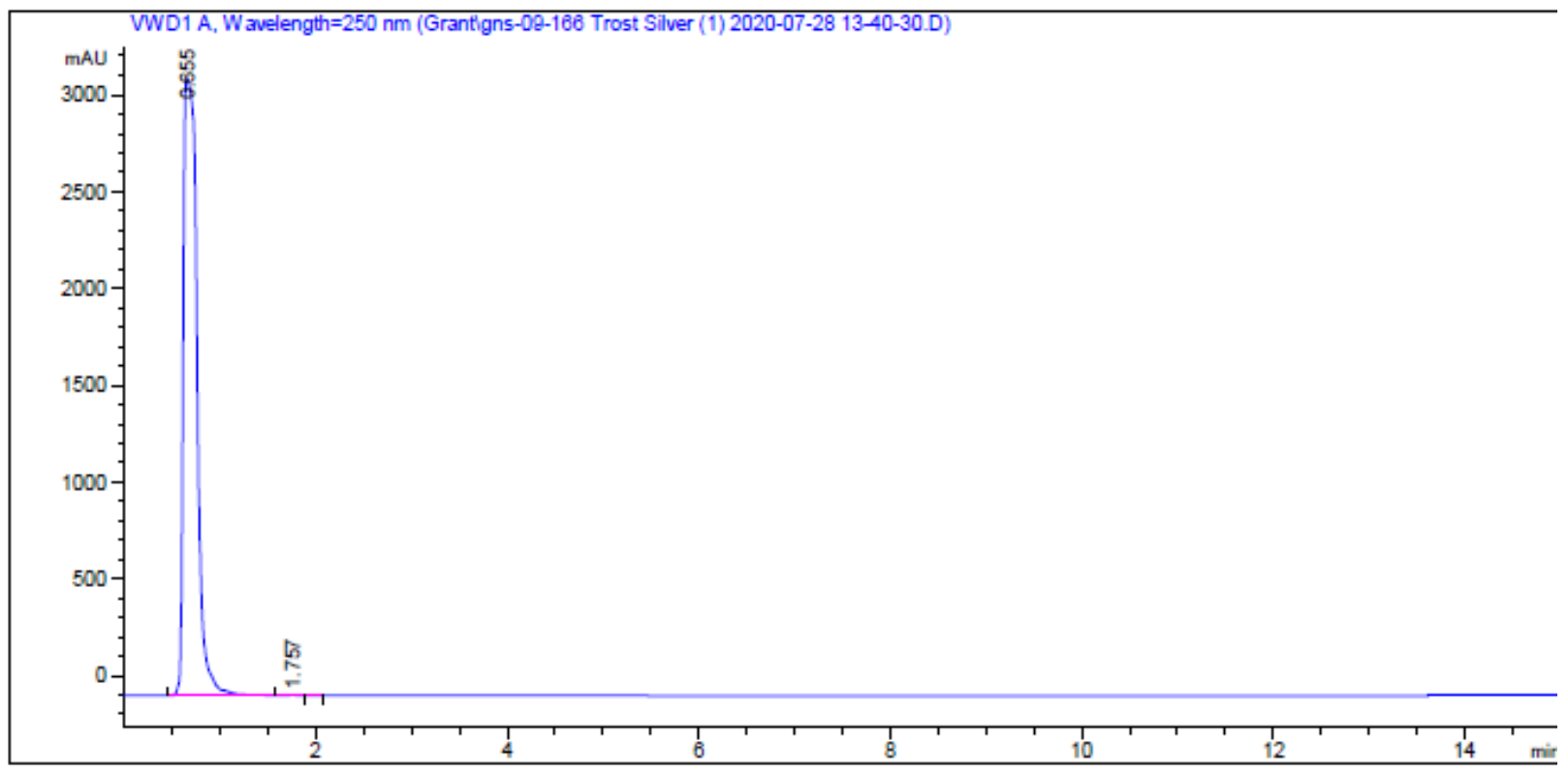

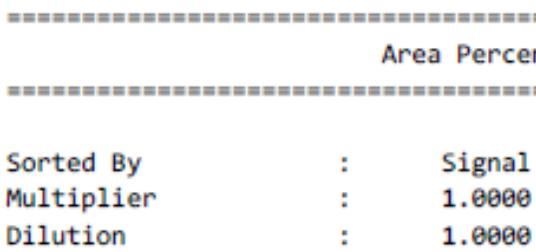

Use Multiplier \& Dilution Factor with ISTDS

Signal 1: WDD1 A, Wavelength $=250 \mathrm{~nm}$

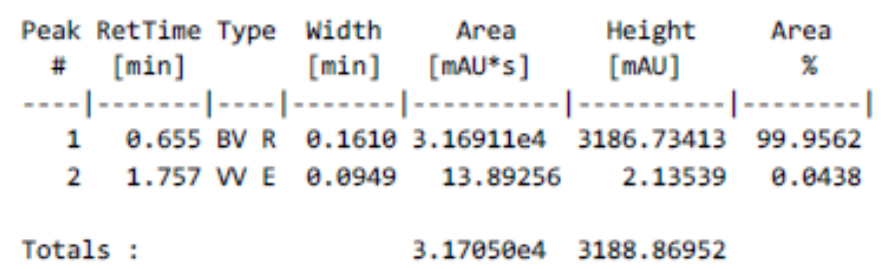




\section{HPLC of compound 20}

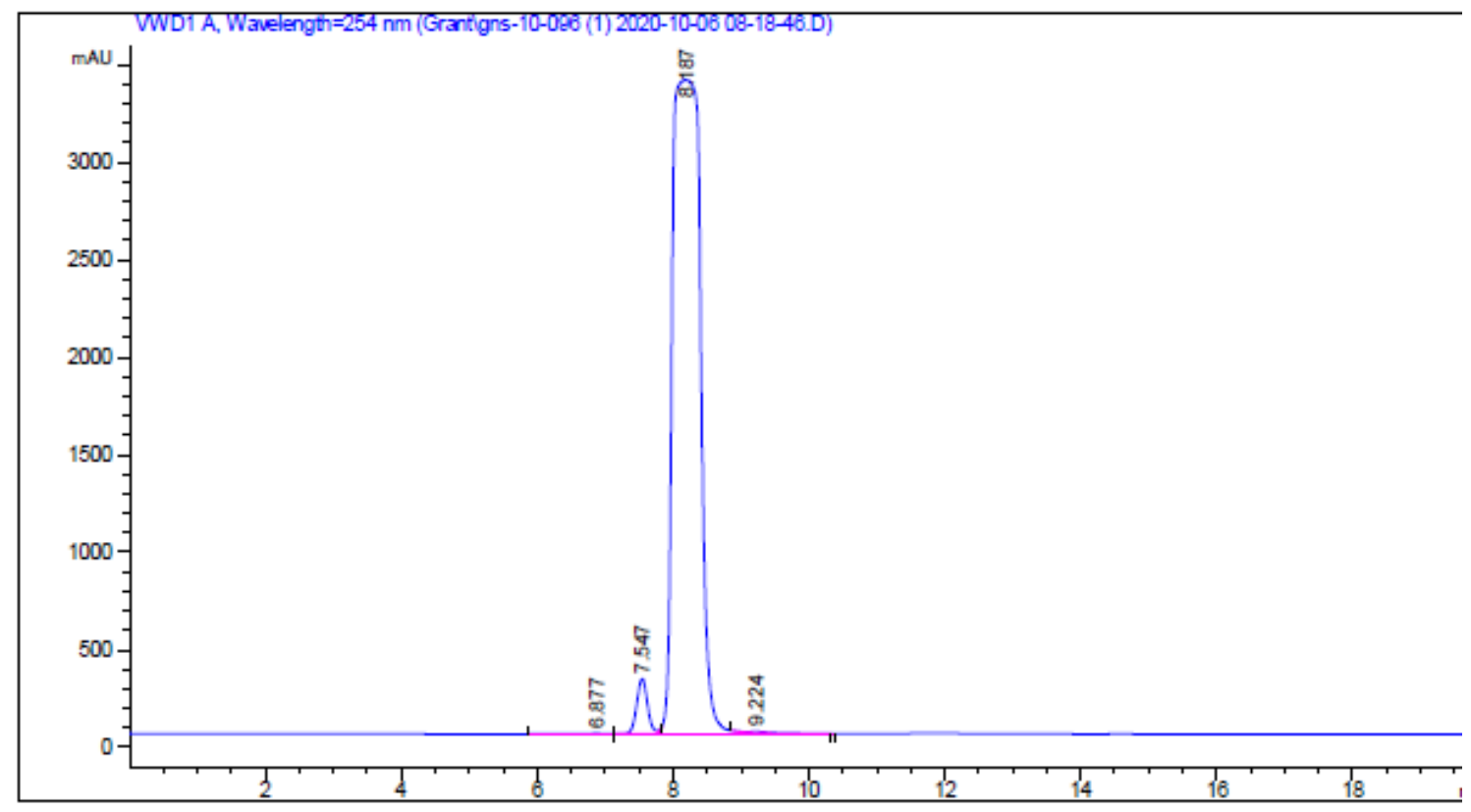

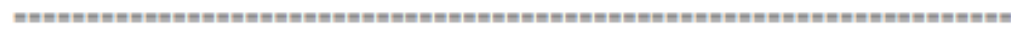

Area Percent Report

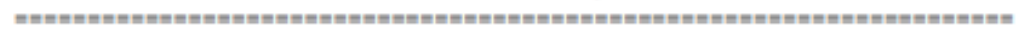

$\begin{array}{lll}\text { Sorted By } & : & \text { Signal } \\ \text { Multiplier } & : & 1.0000 \\ \text { Dilution } & : & 1.0000\end{array}$

Dilution

Use Multiplier \& Dilution Factor with ISTDS

Signal 1: VWD1 A, Wavelength $=254 \mathrm{~nm}$

\begin{tabular}{|c|c|c|c|c|c|c|}
\hline $\begin{array}{c}\text { Peak } \\
\quad \#\end{array}$ & $\begin{array}{c}\text { RetTime } \\
\text { [min] }\end{array}$ & Type & $\begin{array}{l}\text { Width } \\
\text { [min] }\end{array}$ & $\begin{array}{c}\text { Area } \\
{\left[\mathrm{mAU}^{*} \mathrm{~s}\right]}\end{array}$ & $\begin{array}{l}\text { Height } \\
\text { [mAU] }\end{array}$ & $\begin{array}{c}\text { Area } \\
\%\end{array}$ \\
\hline$\cdots$ & & & & |.... & 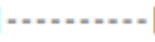 & $=-\infty-\infty$ \\
\hline 1 & 6.877 & BB & 0.1718 & 35.92372 & 3.13324 & 0.0368 \\
\hline 2 & 7.547 & BV E & 0.1694 & 3087.24146 & 280.46259 & 3.1667 \\
\hline 3 & 8.187 & W R & 0.4556 & $9.41335 \mathrm{e} 4$ & 3352.77246 & 96.5555 \\
\hline 4 & 9.224 & VB E & 0.3921 & 234.91112 & 8.01125 & 0.2410 \\
\hline Total & : & & & $9.74916 \mathrm{e} 4$ & 3644.37954 & \\
\hline
\end{tabular}




\section{HPLC of compound 21}

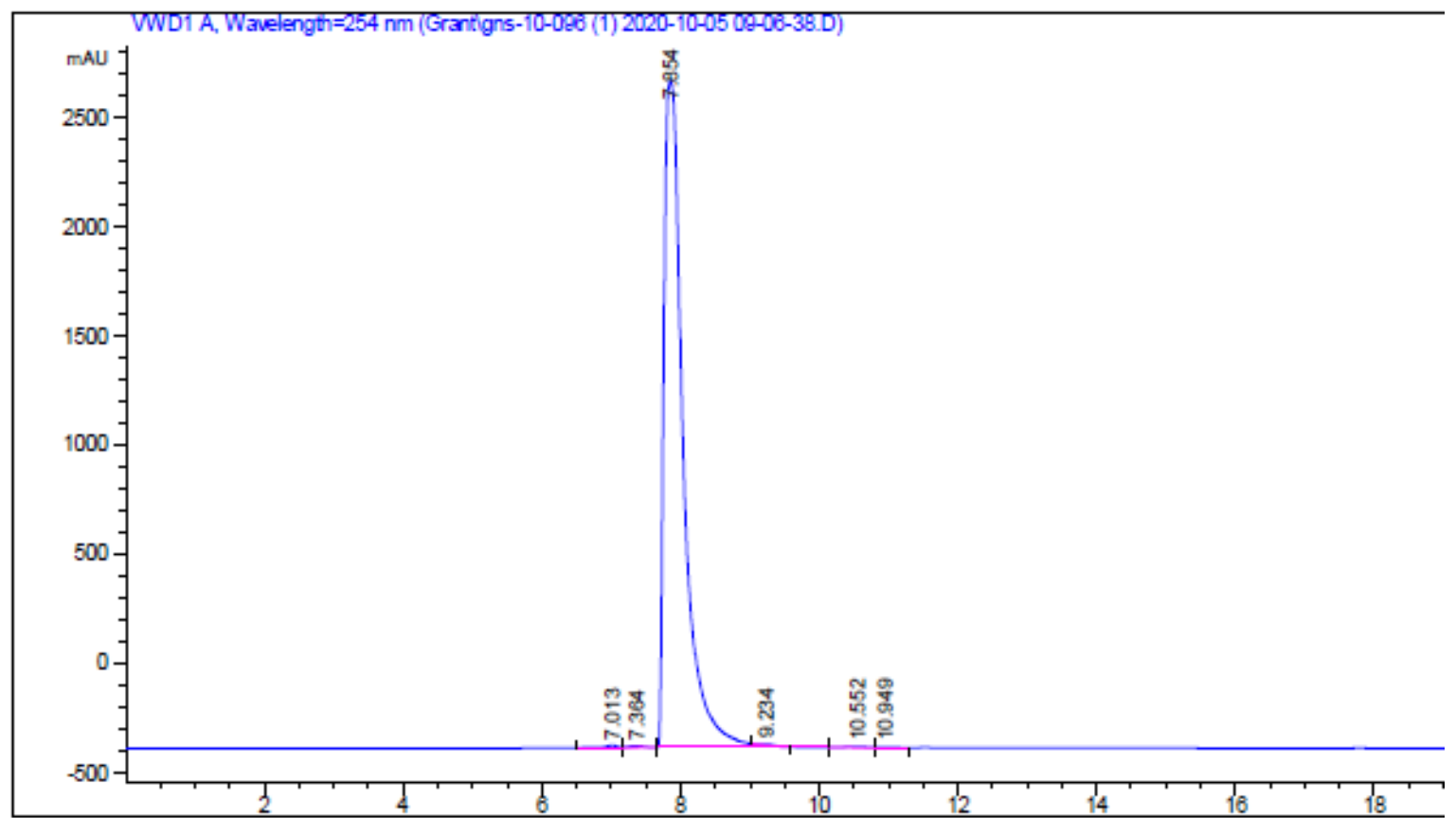

Area Percent Report

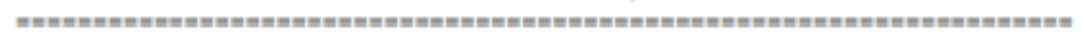

$\begin{array}{lll}\text { Sorted By } & : & \text { Signal } \\ \text { Multiplier } & : & 1.0000 \\ \text { Dilution } & : & 1.0000\end{array}$

Use Multiplier \& Dilution Factor with ISTDs

Signal 1: WD1 A, Wavelength=254 nm

\begin{tabular}{|c|c|c|c|c|c|c|}
\hline $\begin{array}{c}\text { Peak } \\
\#\end{array}$ & $\begin{array}{c}\text { RetTime } \\
\text { [min] }\end{array}$ & Type & $\begin{array}{l}\text { Width } \\
\text { [min] }\end{array}$ & $\begin{array}{c}\text { Area } \\
{\left[\mathrm{mAU}^{*} \mathrm{~s}\right]}\end{array}$ & $\begin{array}{l}\text { Height } \\
\text { [mAU] }\end{array}$ & $\begin{array}{c}\text { Area } \\
\%\end{array}$ \\
\hline & & & & & | - - - - - & $-\infty+\infty-\infty$ \\
\hline 1 & 7.013 & W R & 0.1944 & 147.03461 & 10.76328 & 0.2469 \\
\hline 2 & 7.364 & VB & 0.2404 & 124.14367 & 7.94241 & 0.2085 \\
\hline 3 & 7.854 & BV $R$ & 0.2928 & $5.90561 \mathrm{e} 4$ & 3050.93408 & 99.1726 \\
\hline 4 & 9.234 & VB E & 0.1712 & 81.88514 & 7.22478 & 0.1375 \\
\hline 5 & 10.552 & BV & 0.3637 & 93.91460 & 3.47843 & 0.1577 \\
\hline 6 & 10.949 & VB & 0.2155 & 45.75348 & 3.14895 & 0.0768 \\
\hline
\end{tabular}




\section{HPLC of compound 24}

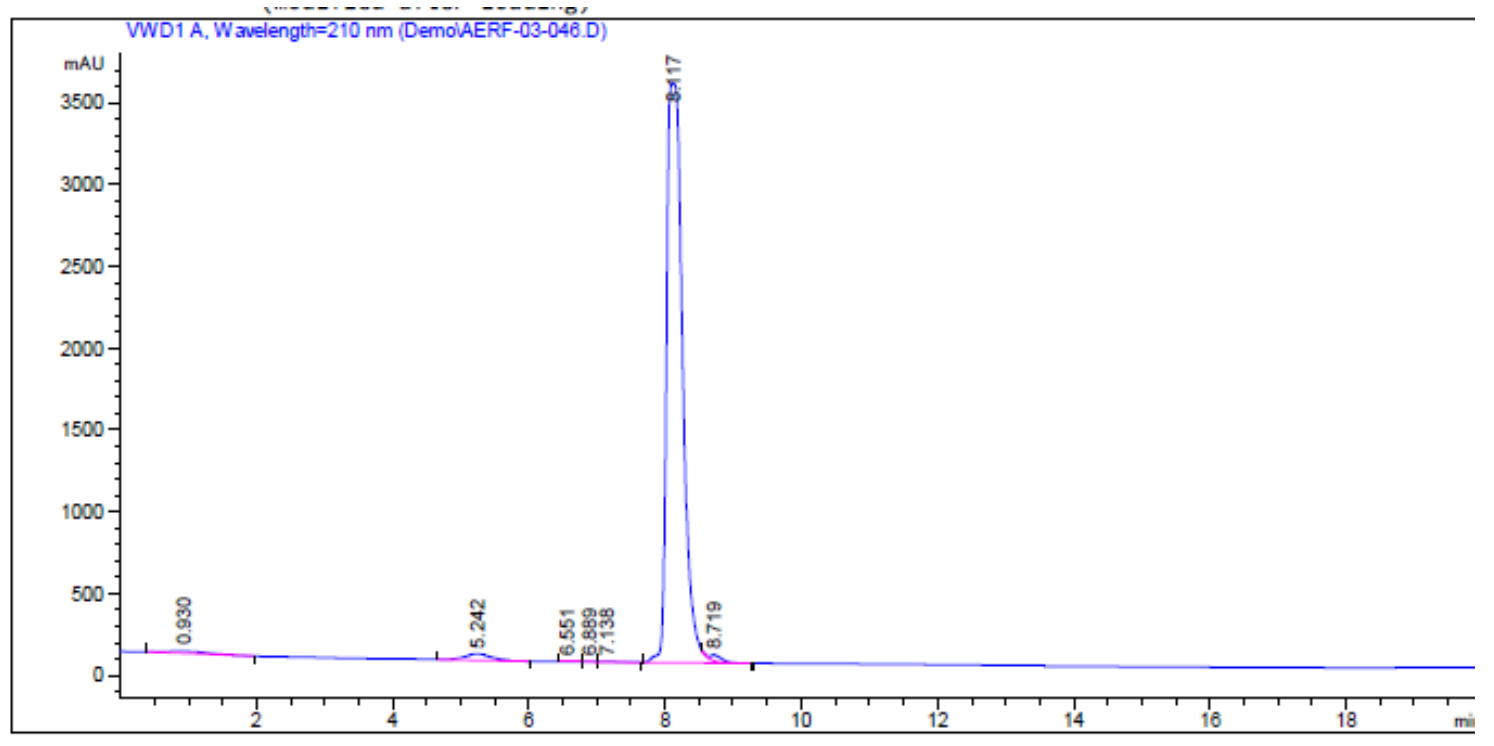

\begin{tabular}{|c|c|c|c|c|}
\hline \multicolumn{5}{|c|}{ Area Percent Report } \\
\hline Sorted By & : & Signal & & \\
\hline Multiplier & : & 1.0000 & & \\
\hline Dilution & : & 1.0000 & & \\
\hline \multicolumn{5}{|c|}{ Use Multiplier \& Dilution Factor with ISTDs } \\
\hline \multicolumn{5}{|c|}{ Signal 1: WWD1 A, Wavelength $=210 \mathrm{~nm}$} \\
\hline $\begin{array}{l}\text { Peak RetTime Type } \\
\# \quad[\text { min] }\end{array}$ & $\begin{array}{l}\text { Width } \\
\text { [min] }\end{array}$ & $\begin{array}{c}\text { Area } \\
{\left[\mathrm{mAU}{ }^{*} \mathrm{~s}\right]}\end{array}$ & $\begin{array}{l}\text { Height } \\
\text { [mAU] }\end{array}$ & $\begin{array}{c}\text { Area } \\
\quad \%\end{array}$ \\
\hline$m-n|-m-n|-n \mid$ & $-\infty-\infty$ & $|-n-n-n|$ & $|-n-n-n|$ & $-\infty-2-1$ \\
\hline $10.930 \mathrm{BB}$ & 0.6848 & 533.92792 & 12.17212 & 0.8897 \\
\hline $5.242 \mathrm{BB}$ & 0.4186 & 1057.85889 & 38.73940 & 1.7627 \\
\hline $6.551 \mathrm{~W}$ & 0.2648 & 34.64897 & 2.33912 & 0.0577 \\
\hline $6.889 \mathrm{~W}$ & 0.1795 & 20.01683 & 1.71111 & 0.0334 \\
\hline 7.138 VB & 0.2354 & 78.02277 & 4.73120 & 0.1360 \\
\hline 8.117 BV R & 0.2524 & $5.78196 \mathrm{e} 4$ & 3542.59888 & 96.3466 \\
\hline
\end{tabular}




\section{LCMS of compound 25}

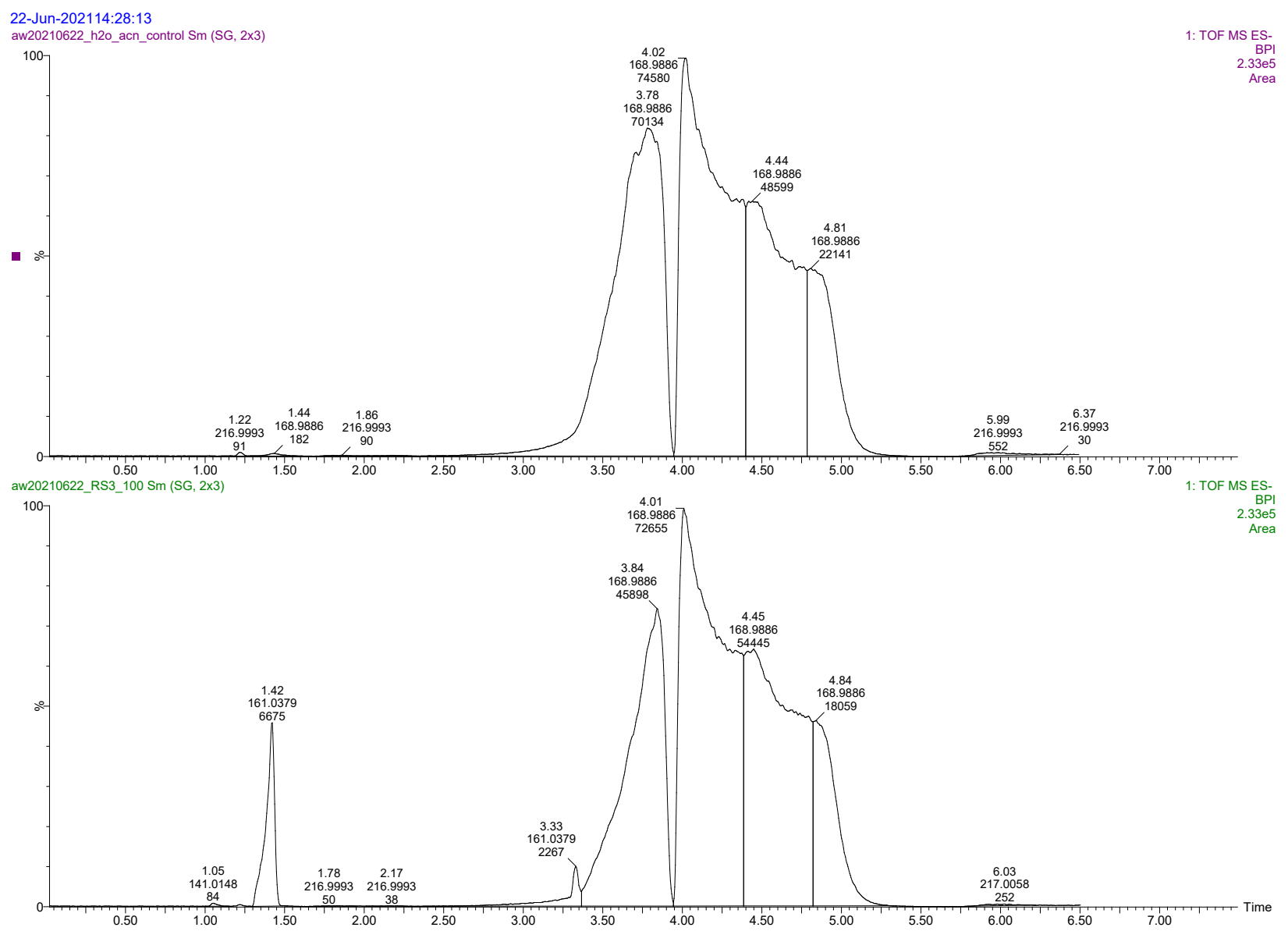

*top panel $=$ water in acetonitrile, bottom panel $=$ compound 25 in acetonitrile 


\section{NMR Spectra}

\section{${ }^{1} \mathrm{H}$ NMR spectrum of compound $8(500 \mathrm{MHz})$}

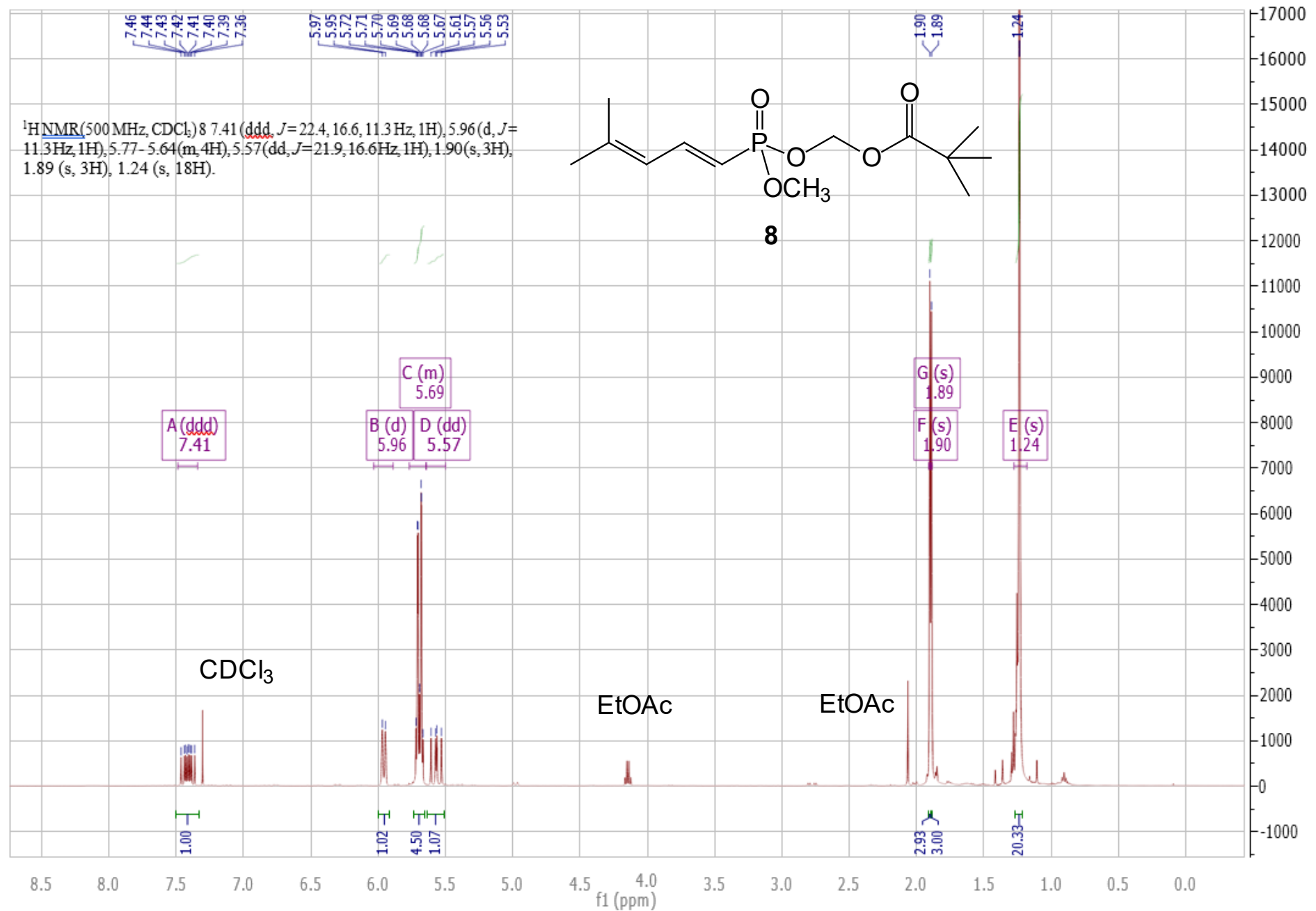


${ }^{13} \mathrm{C}$ NMR spectrum of compound 8 (126 MHz)

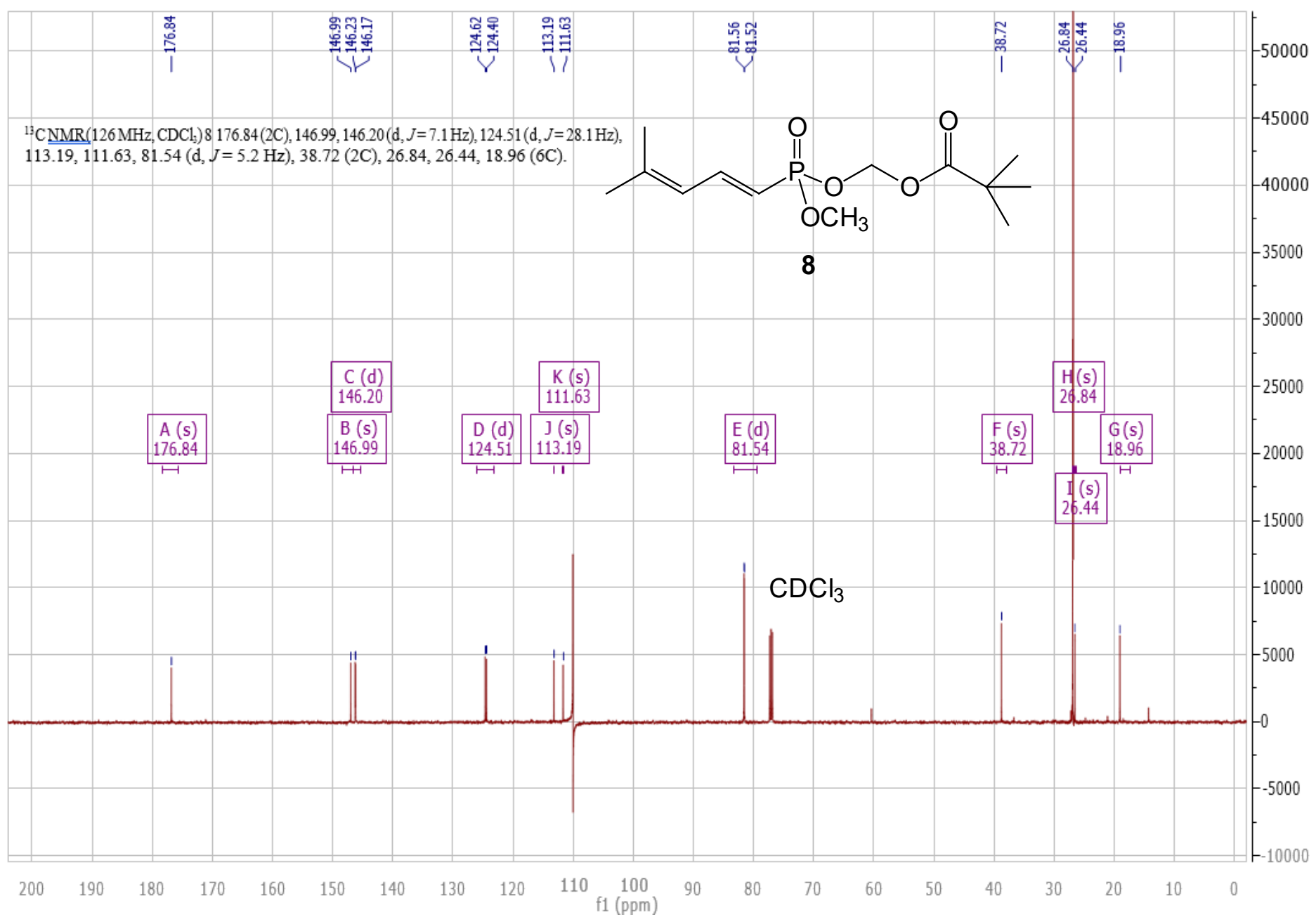


${ }^{31} \mathrm{P}$ NMR spectrum of compound 8 (202 MHz)

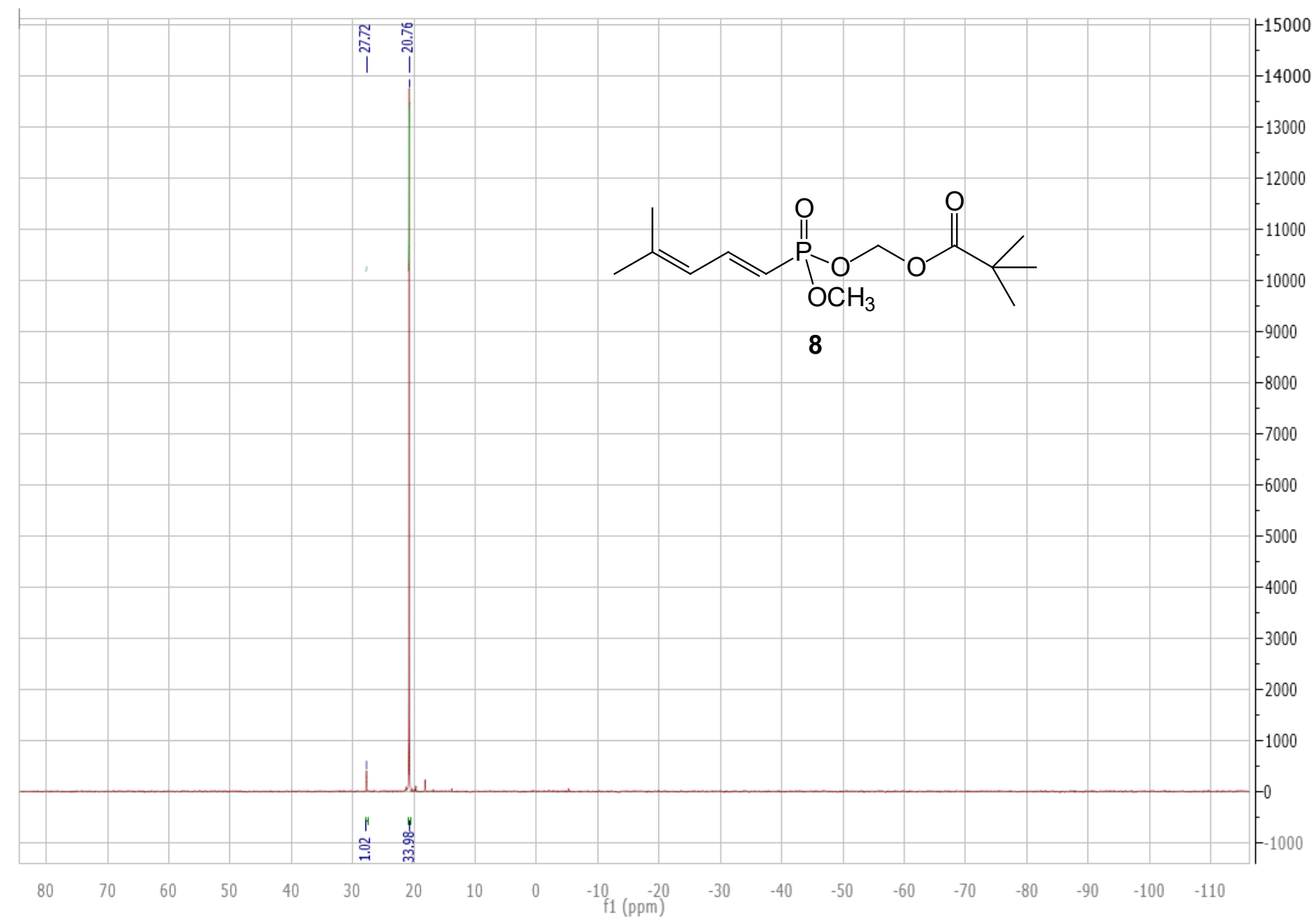


${ }^{1} \mathrm{H}$ NMR spectrum of compound $9(500 \mathrm{MHz})$

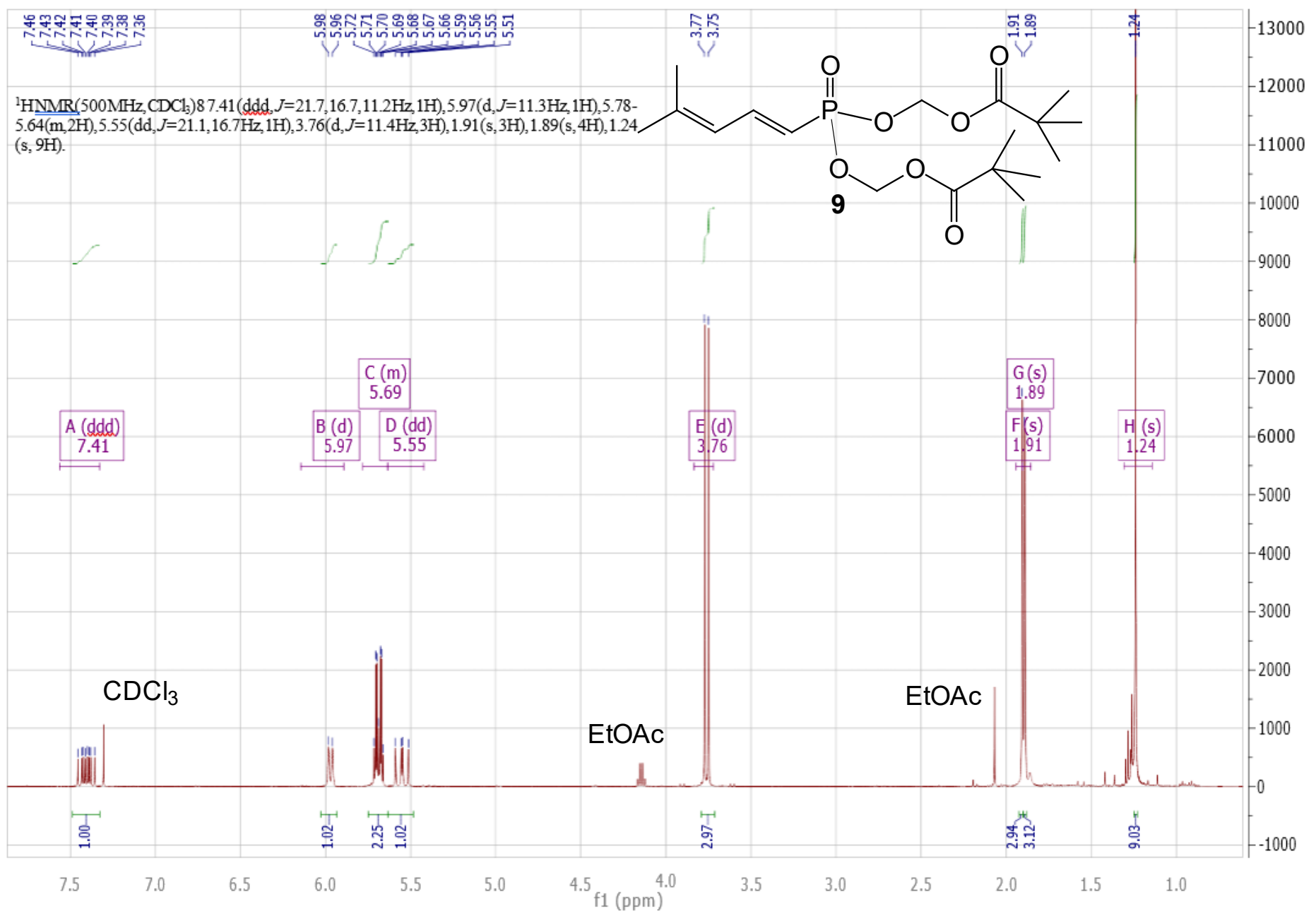


${ }^{13} \mathrm{C}$ NMR spectrum of compound 9 (126 MHz)

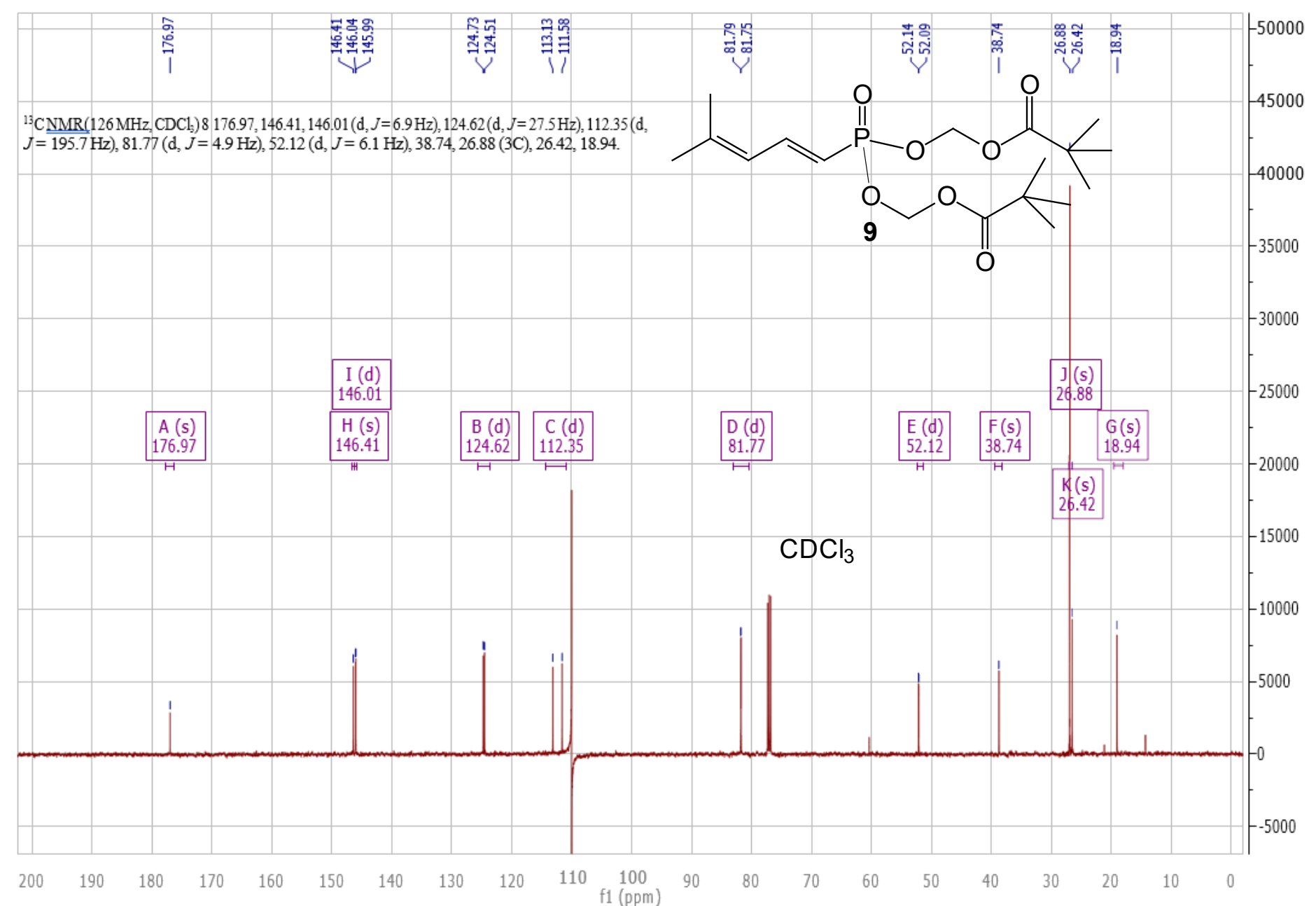


${ }^{31} \mathrm{P}$ NMR spectrum of compound 9 (202 MHz)

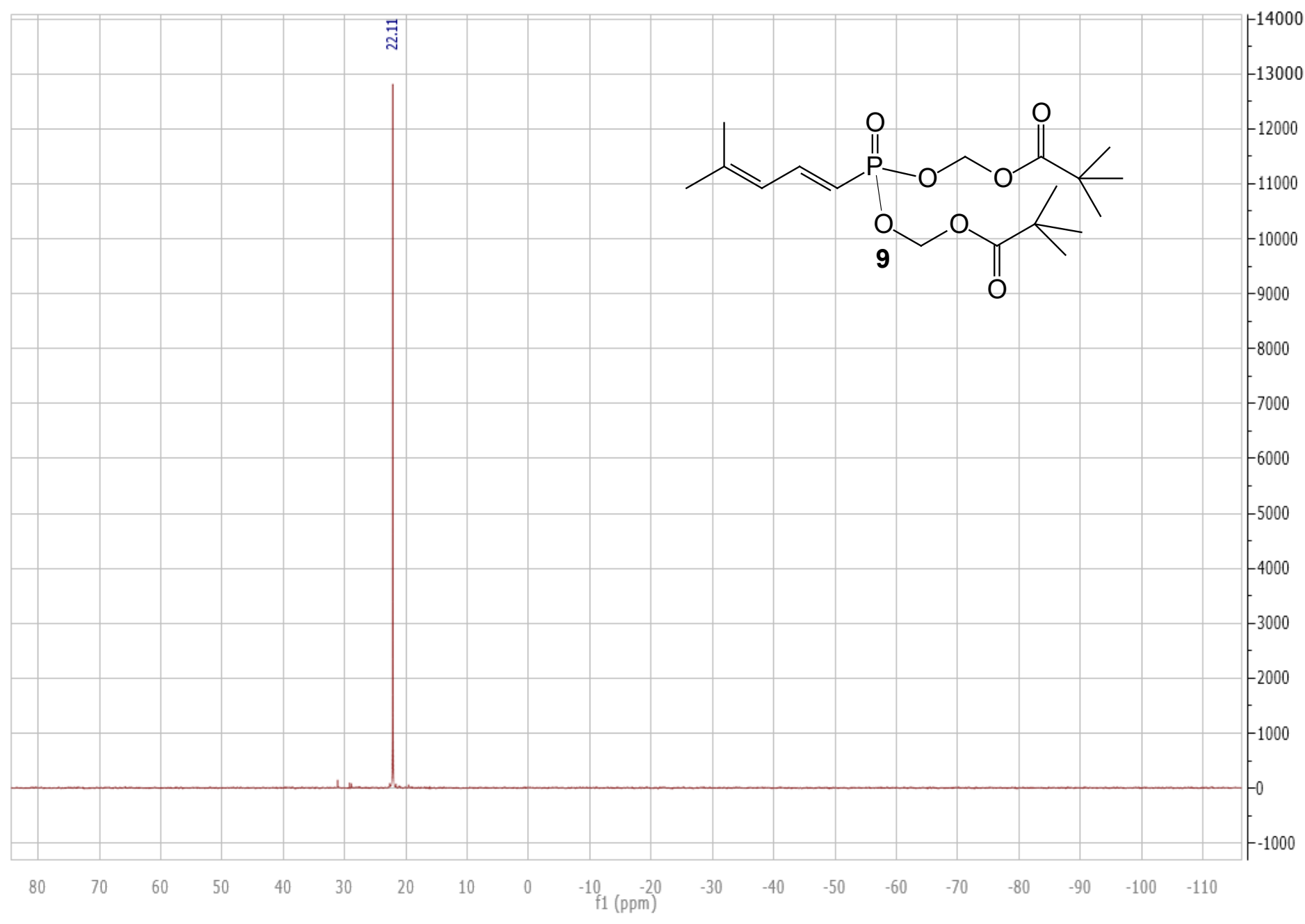


${ }^{1} \mathrm{H}$ NMR spectrum of compound 13 (500 MHz)

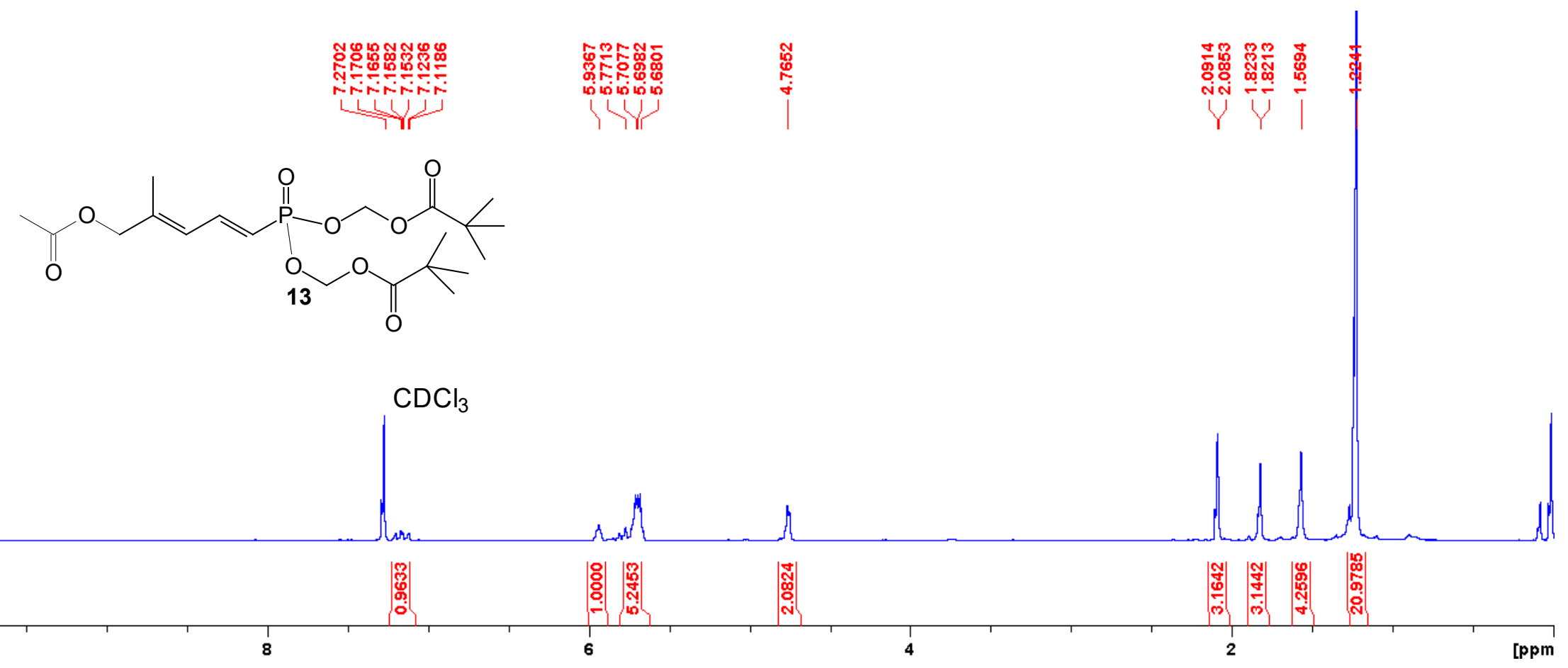


${ }^{13} \mathrm{C}$ NMR spectrum of compound 13 (126 MHz)

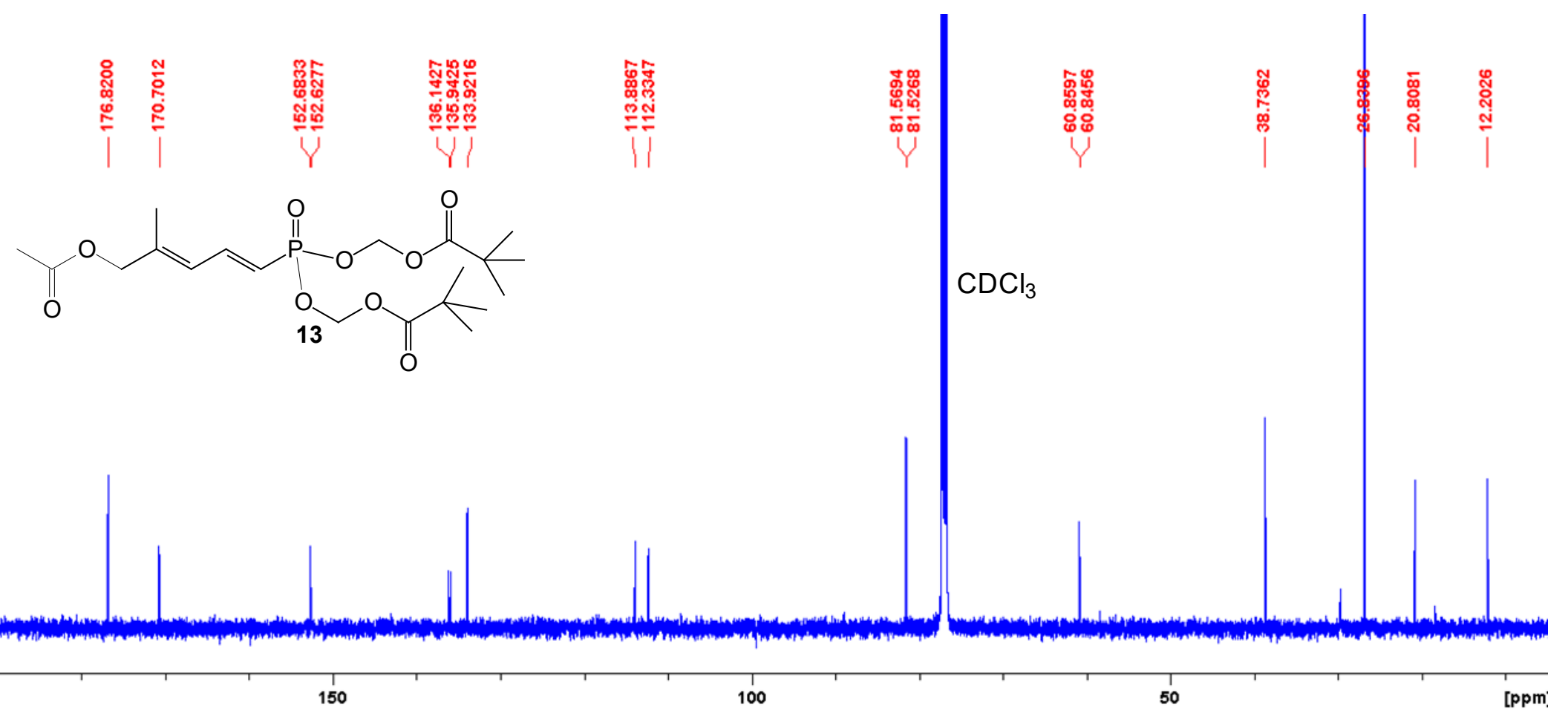


${ }^{31} \mathrm{P}$ NMR spectrum of compound 13 (162 MHz)

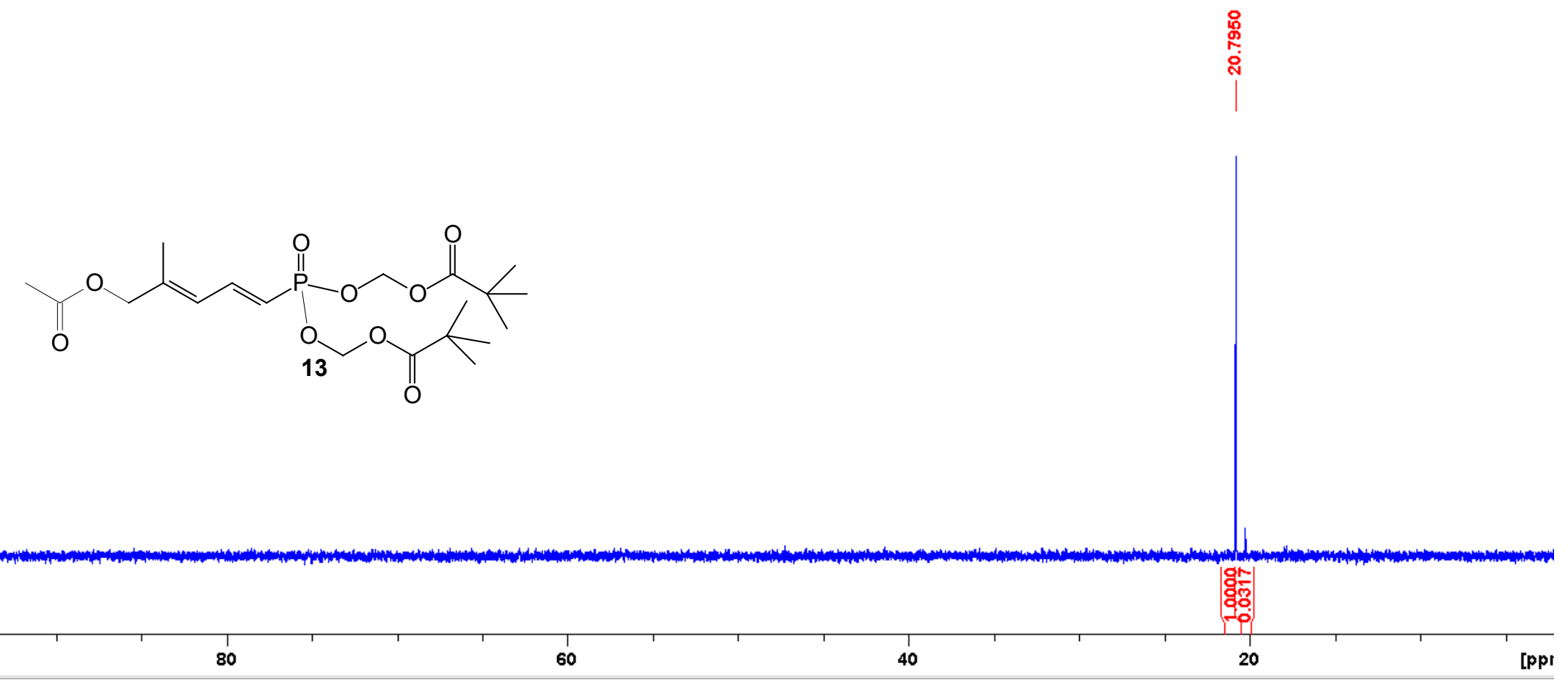


${ }^{1} \mathrm{H}$ NMR spectrum of compound 16 (400 MHz)

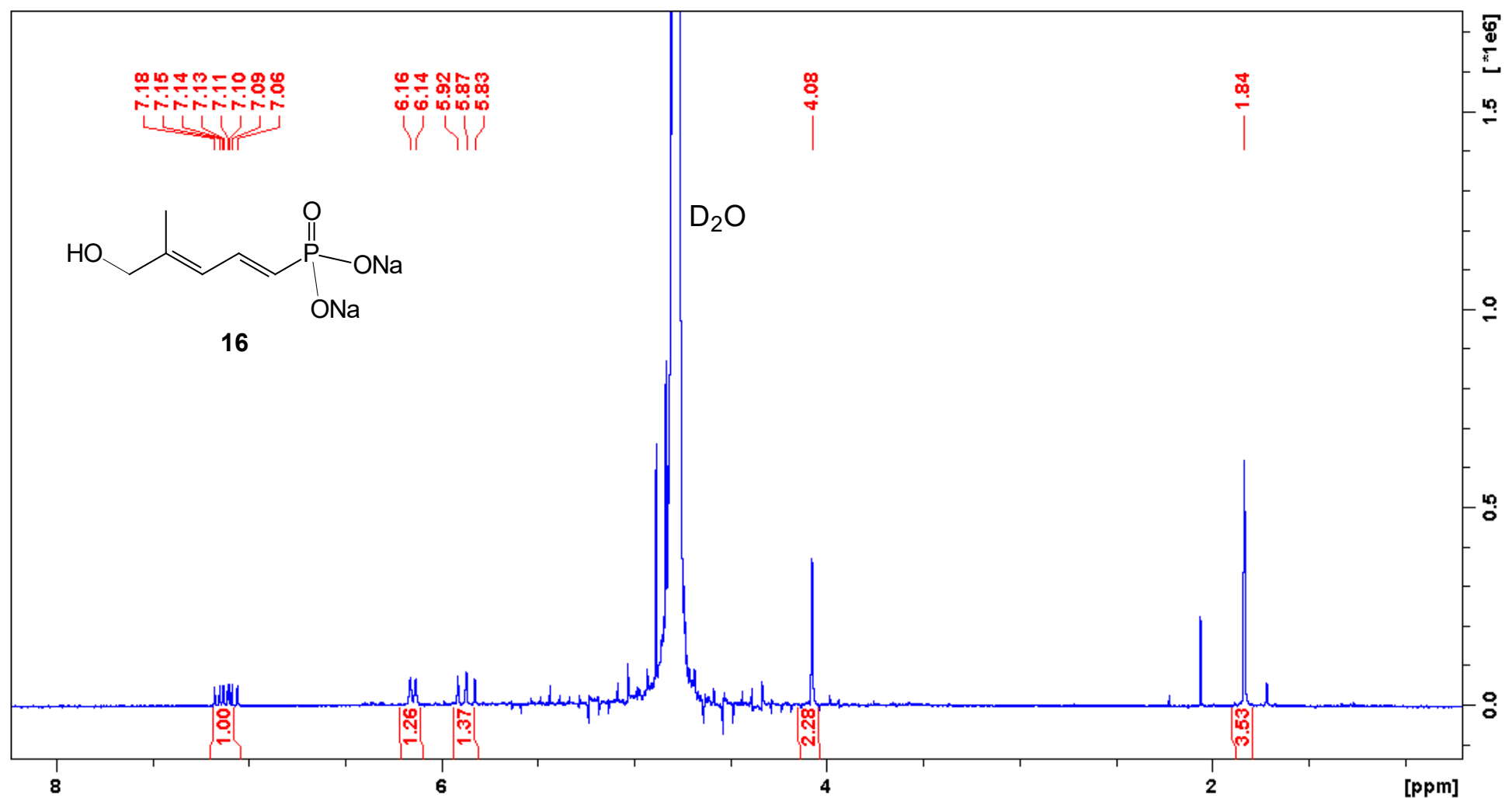


${ }^{31} \mathrm{P}$ NMR spectrum of compound 16 (162 MHz)

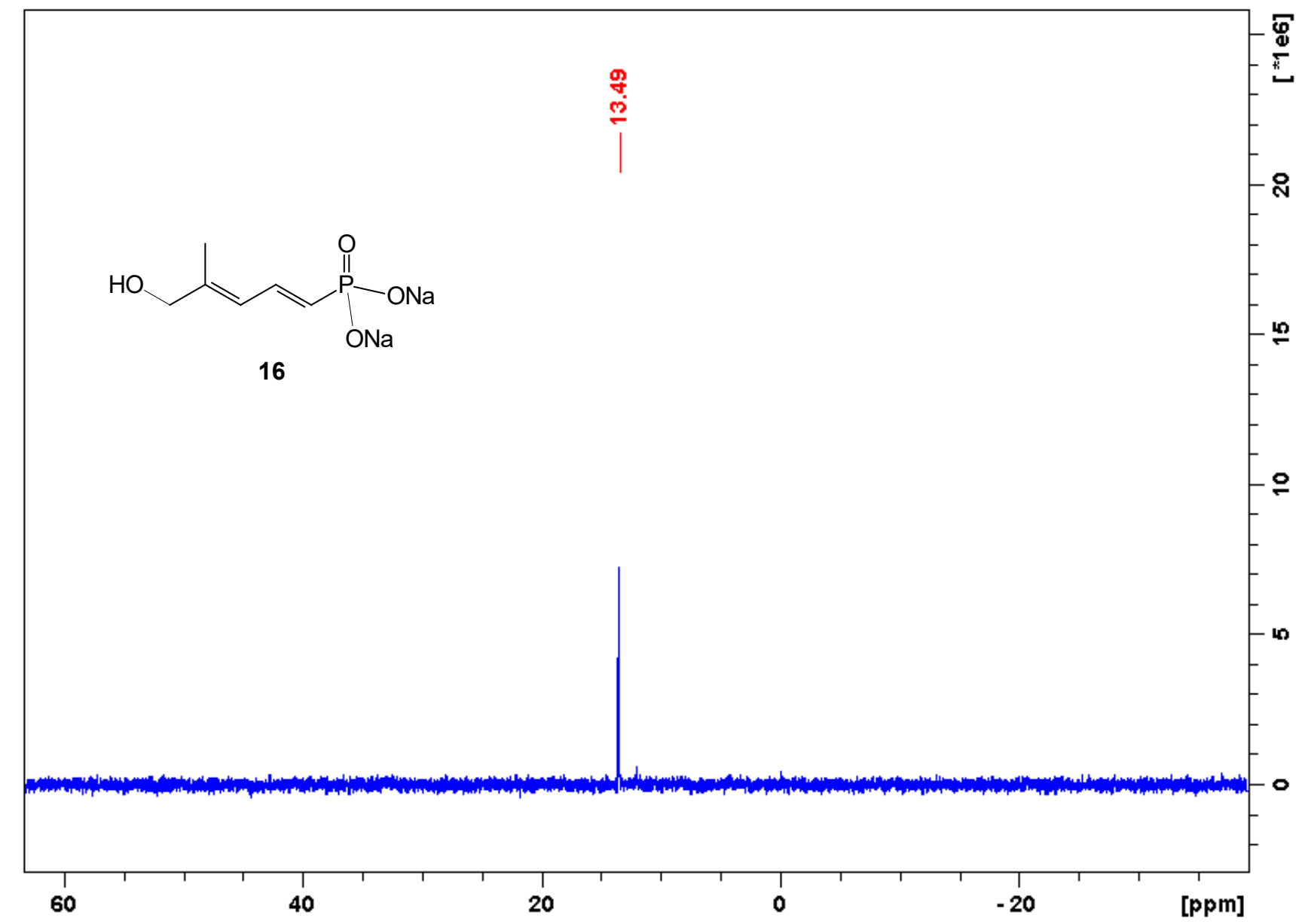


${ }^{1} \mathrm{H}$ NMR spectrum of compound 20 (400 MHz)
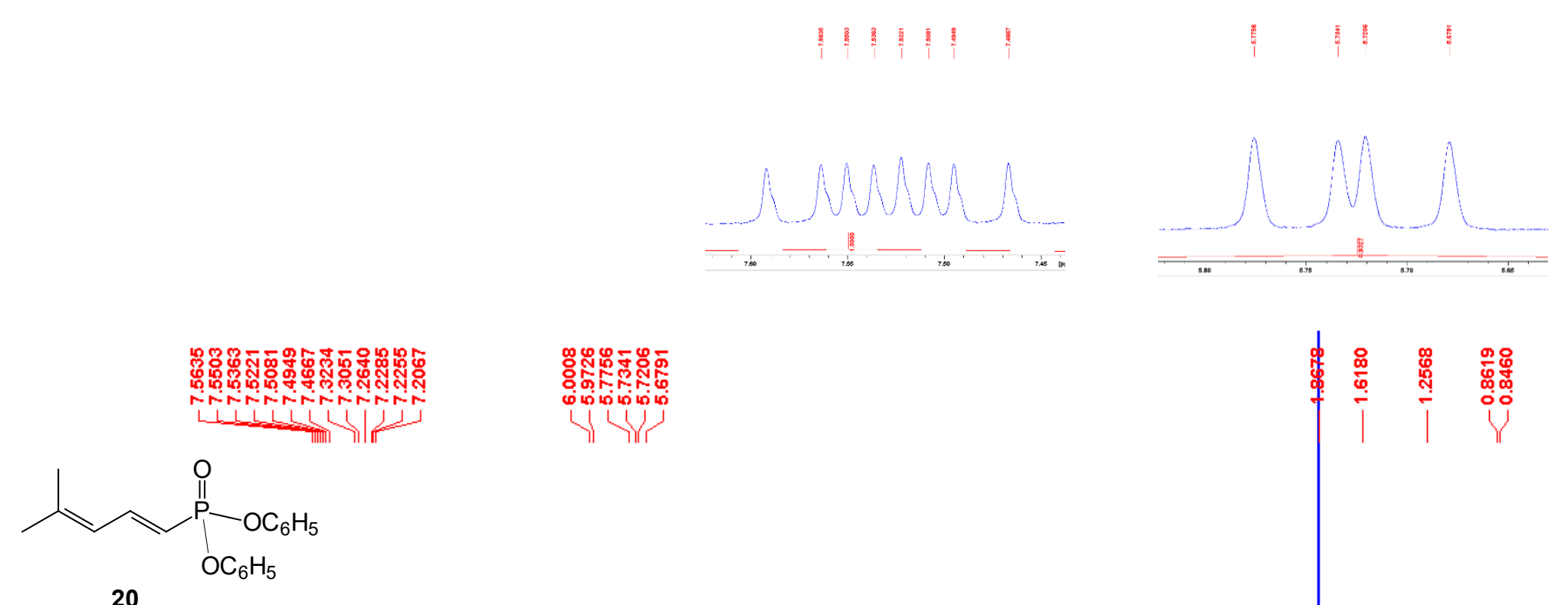

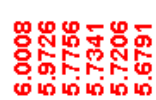

पो पो

20

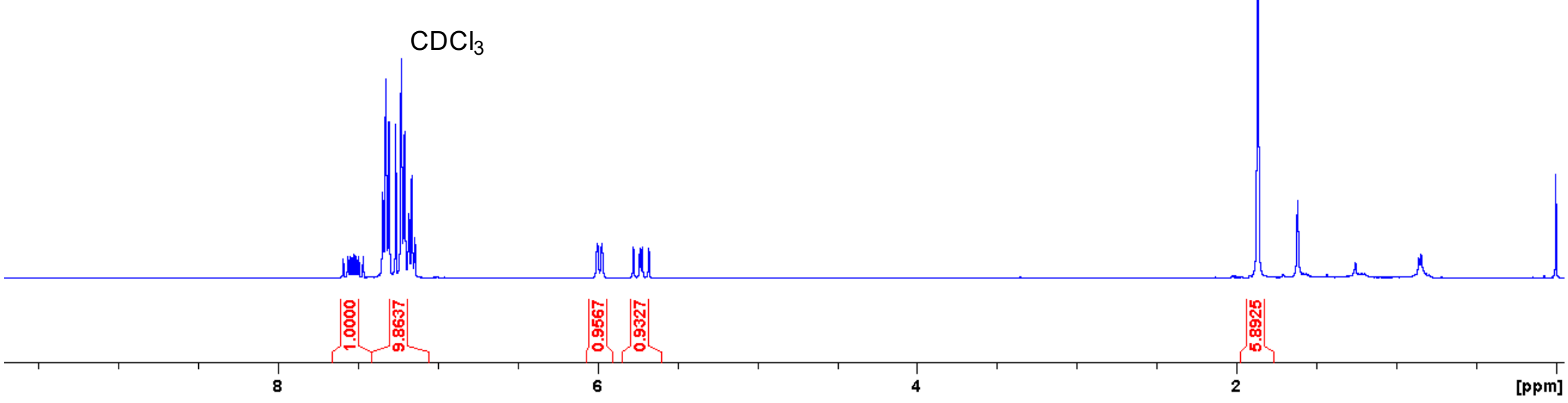


${ }^{13} \mathrm{C}$ NMR spectrum of compound $20(100 \mathrm{MHz})$

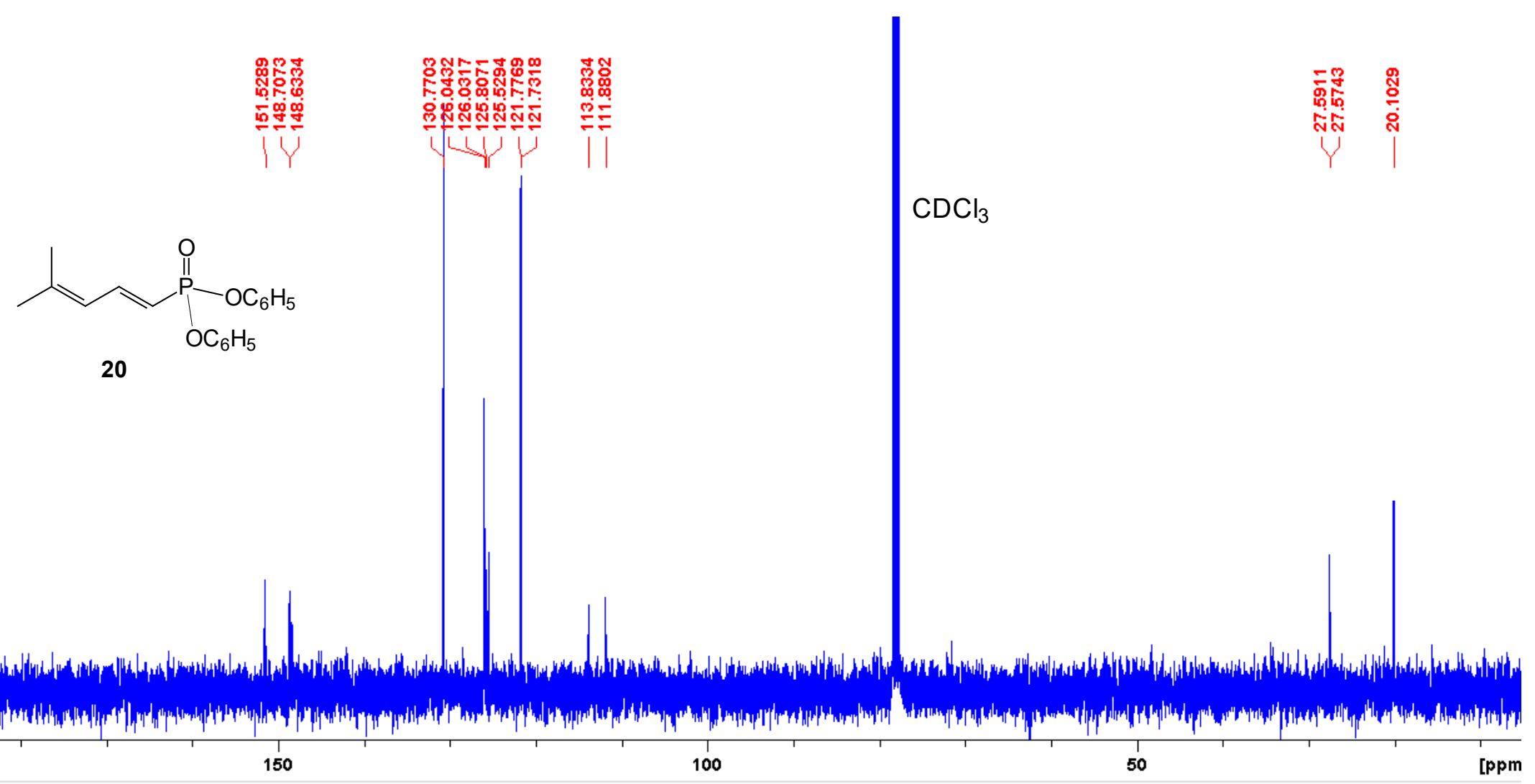


${ }^{31} \mathrm{P}$ NMR spectrum of compound 20 (162 MHz)

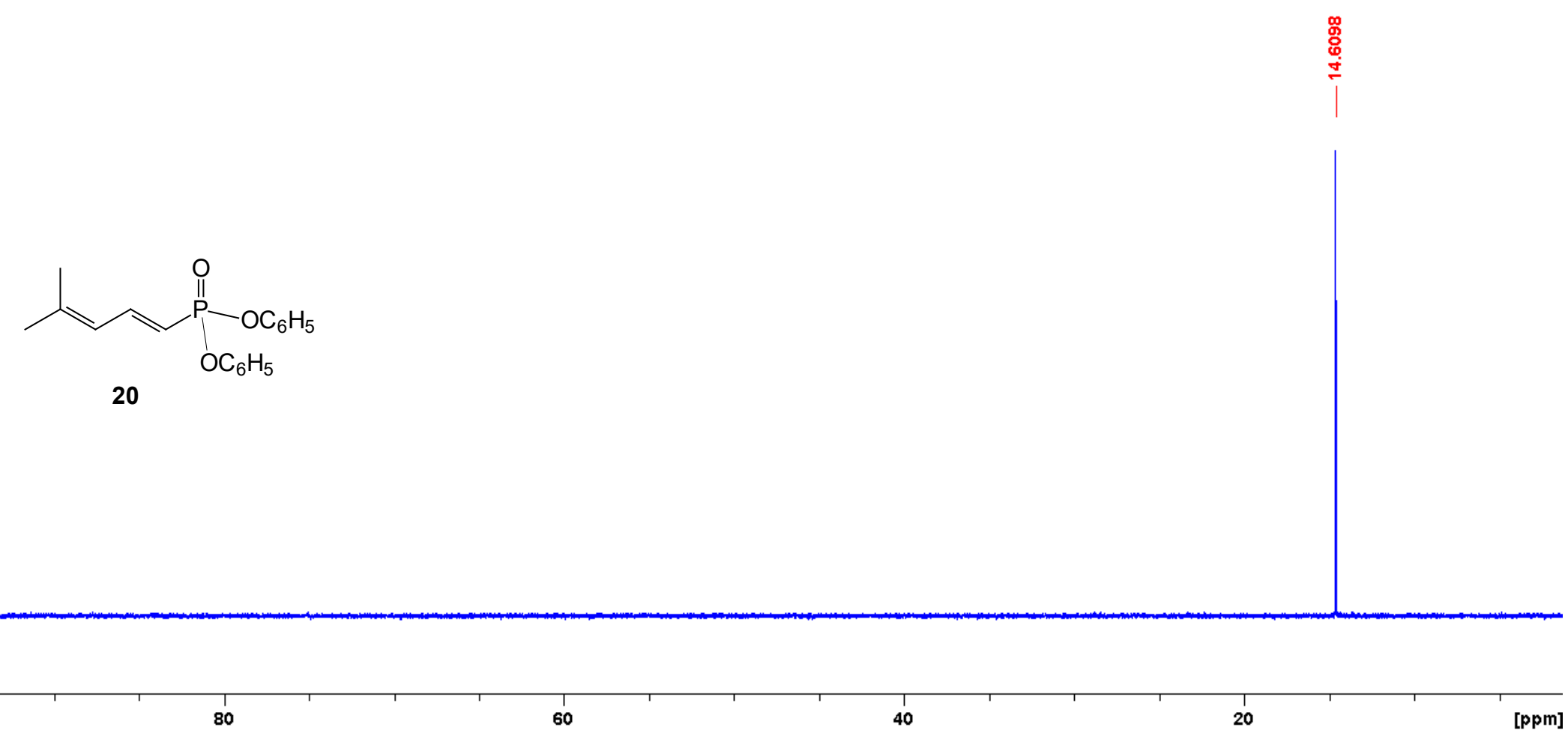


${ }^{1} \mathrm{H}$ NMR spectrum of compound 21 (400 MHz)

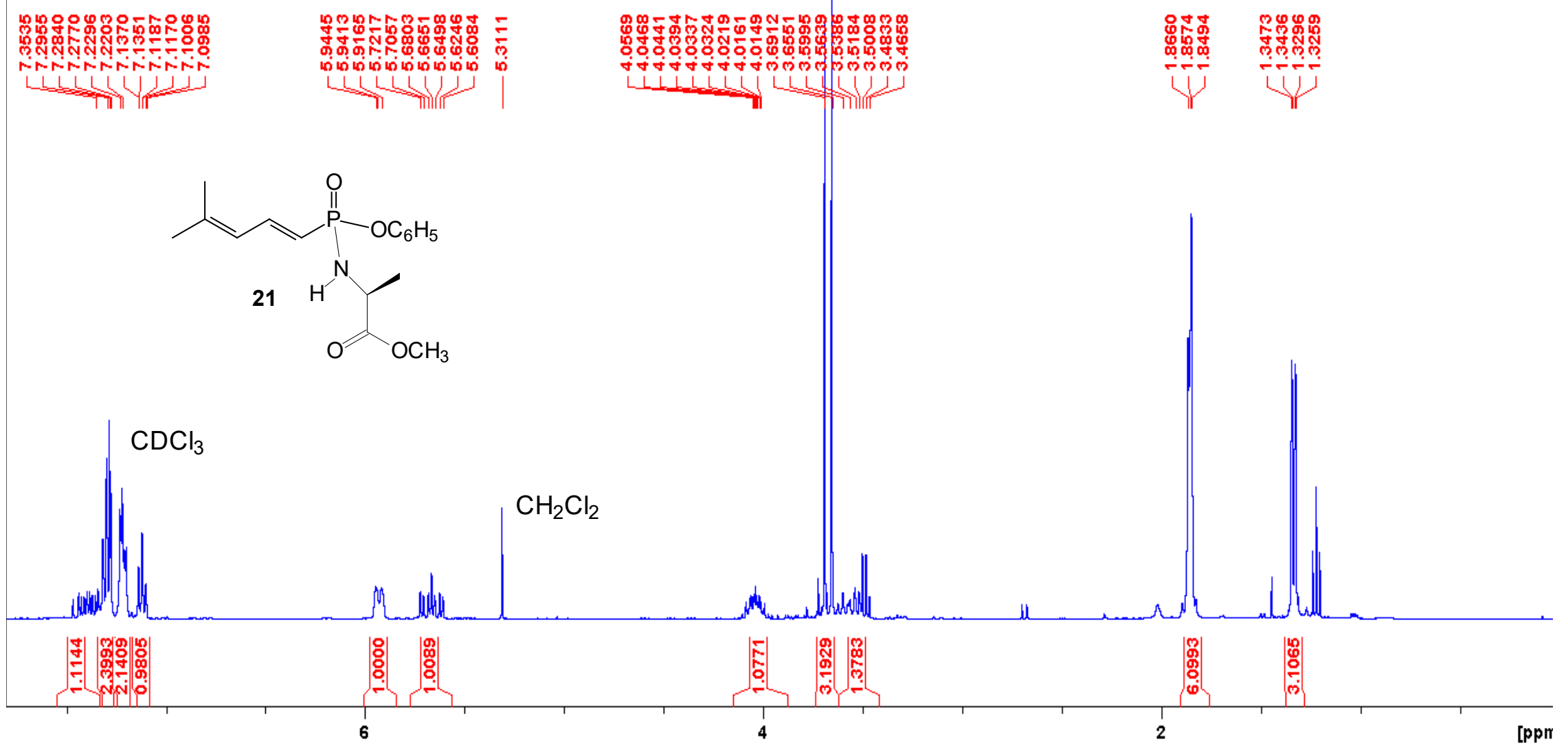


${ }^{13} \mathrm{C}$ NMR spectrum of compound $21(100 \mathrm{MHz})$

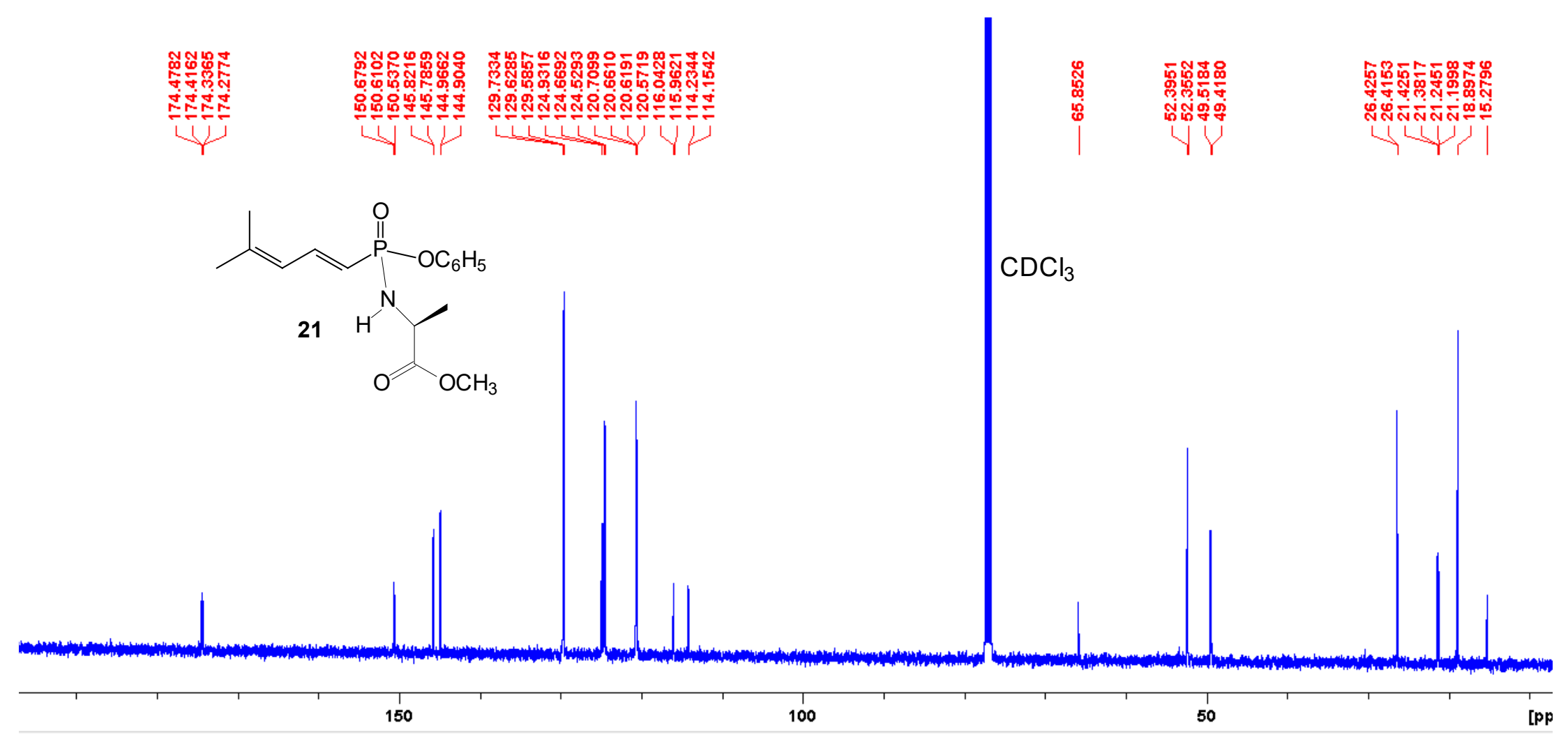


${ }^{31} \mathrm{P}$ NMR spectrum of compound 21 (121 MHz)

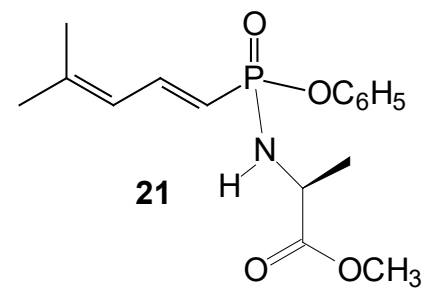


${ }^{1} \mathrm{H}$ NMR spectrum of compound 24 (300 MHz)

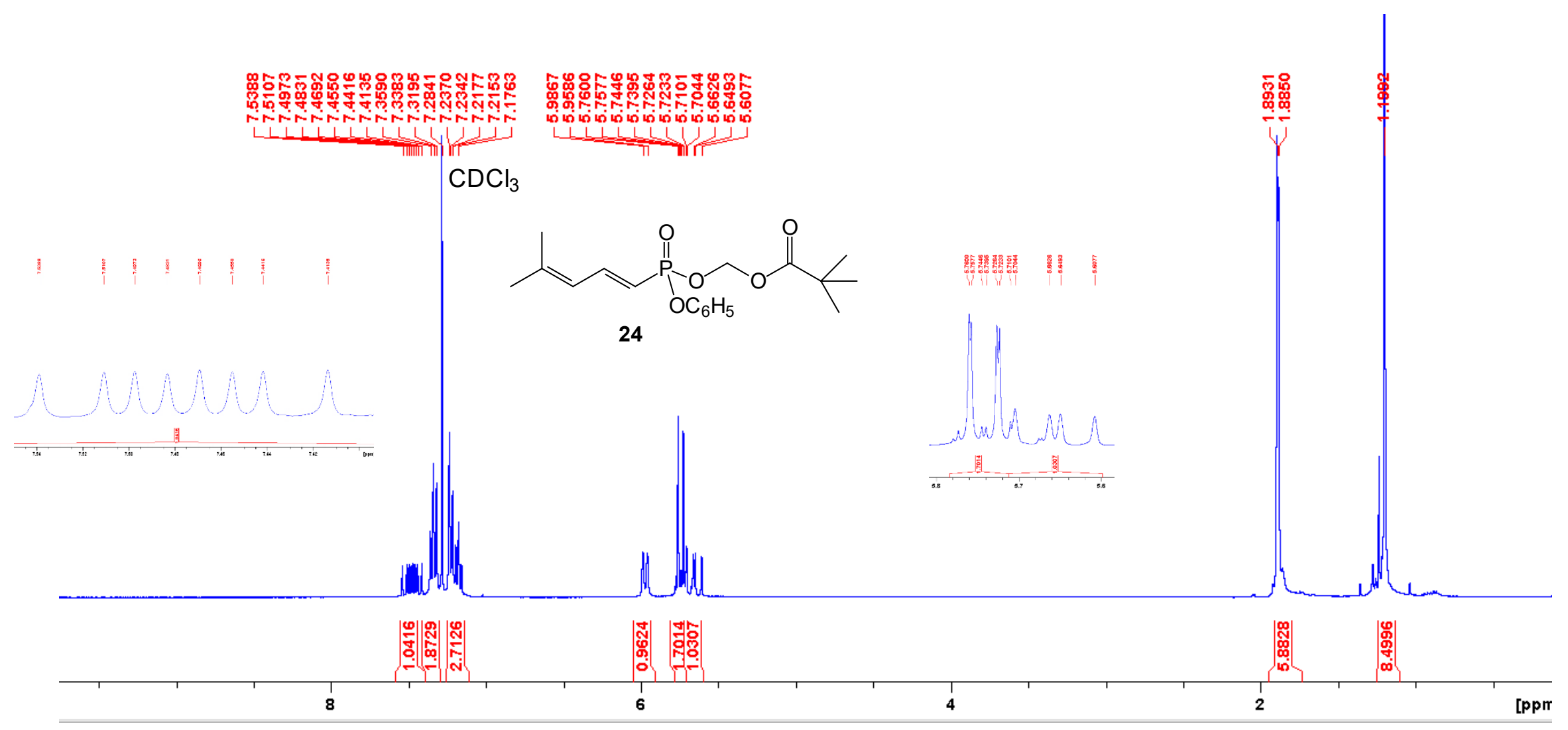


${ }^{13} \mathrm{C}$ NMR spectrum of compound 24 (100 MHz)

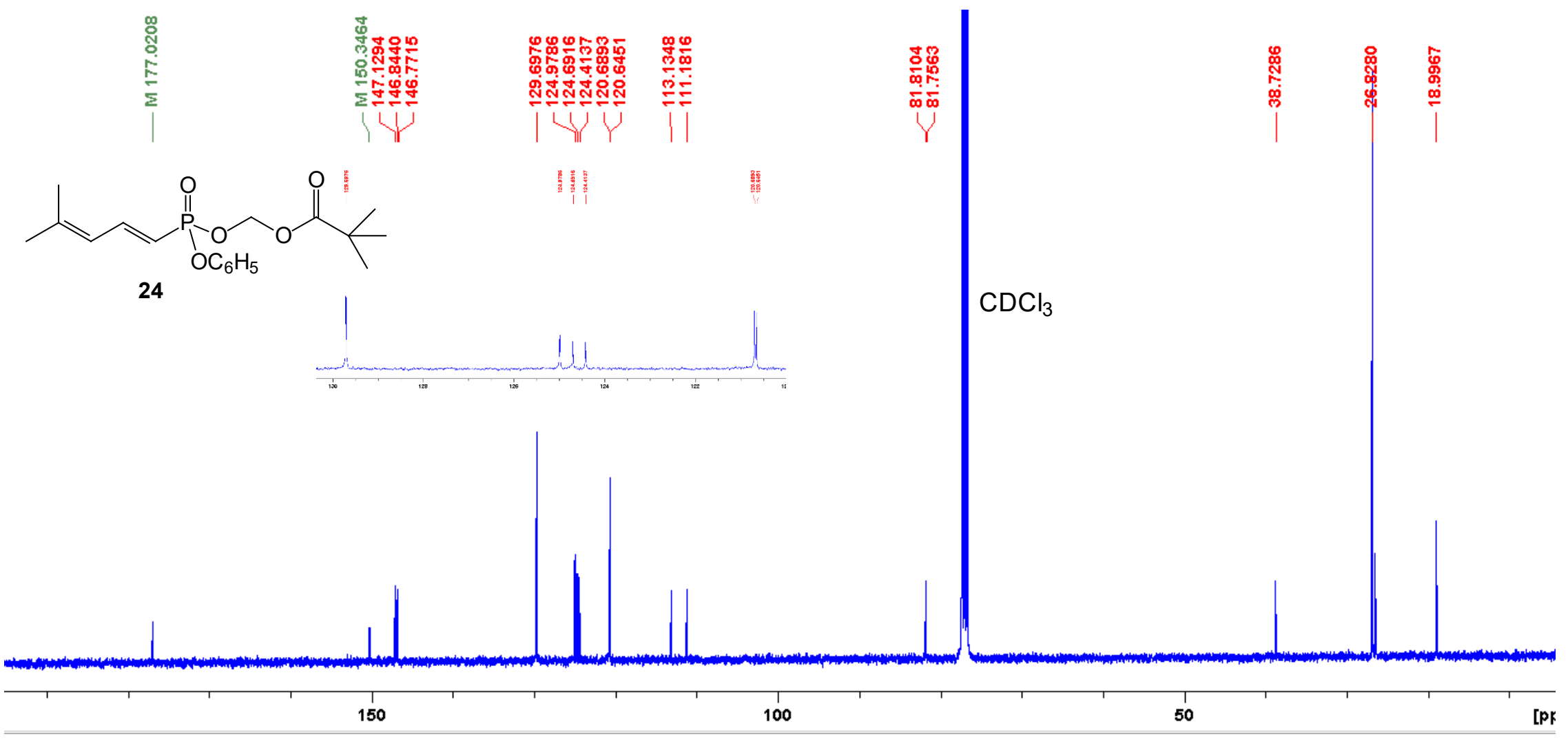


${ }^{31} \mathrm{P}$ NMR spectrum of compound 24 (121 MHz)
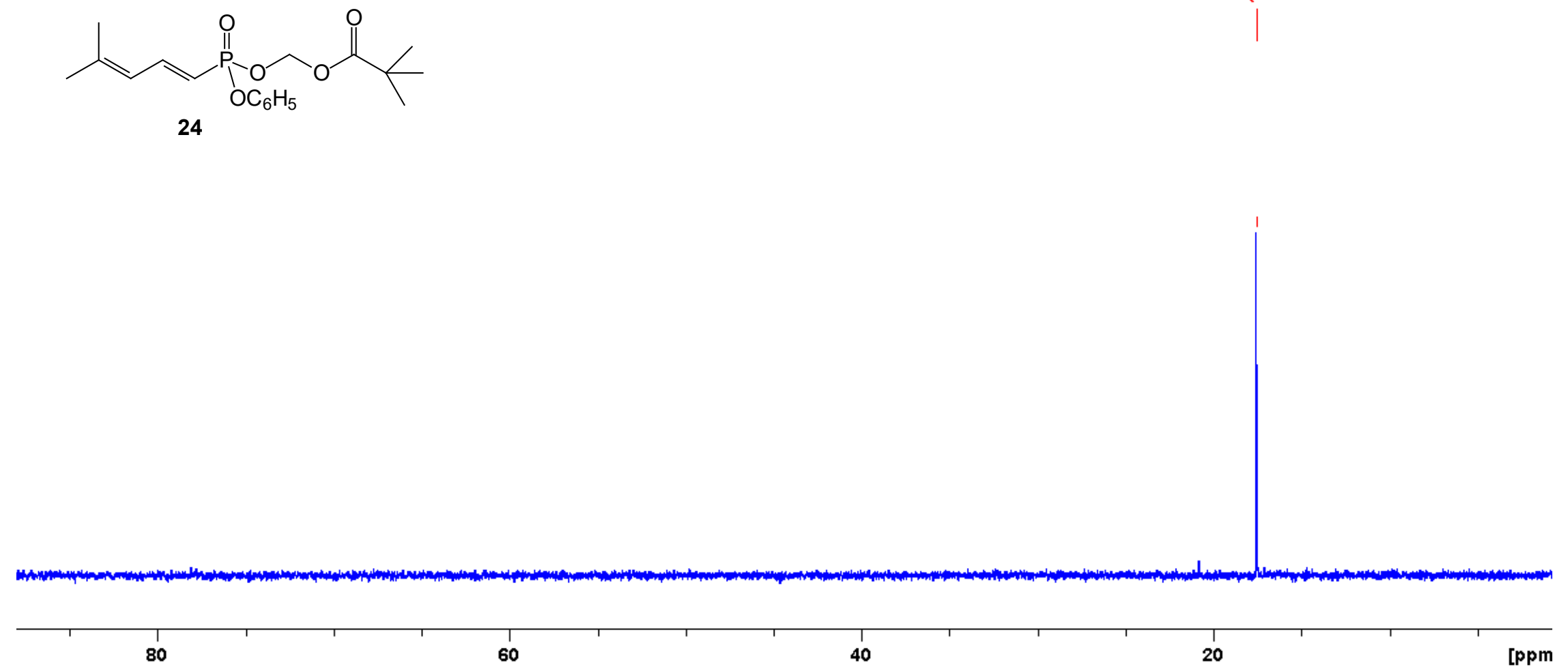
${ }^{1} \mathrm{H}$ NMR spectrum of compound 25 (500 MHz)

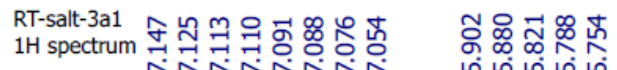

H spectrum
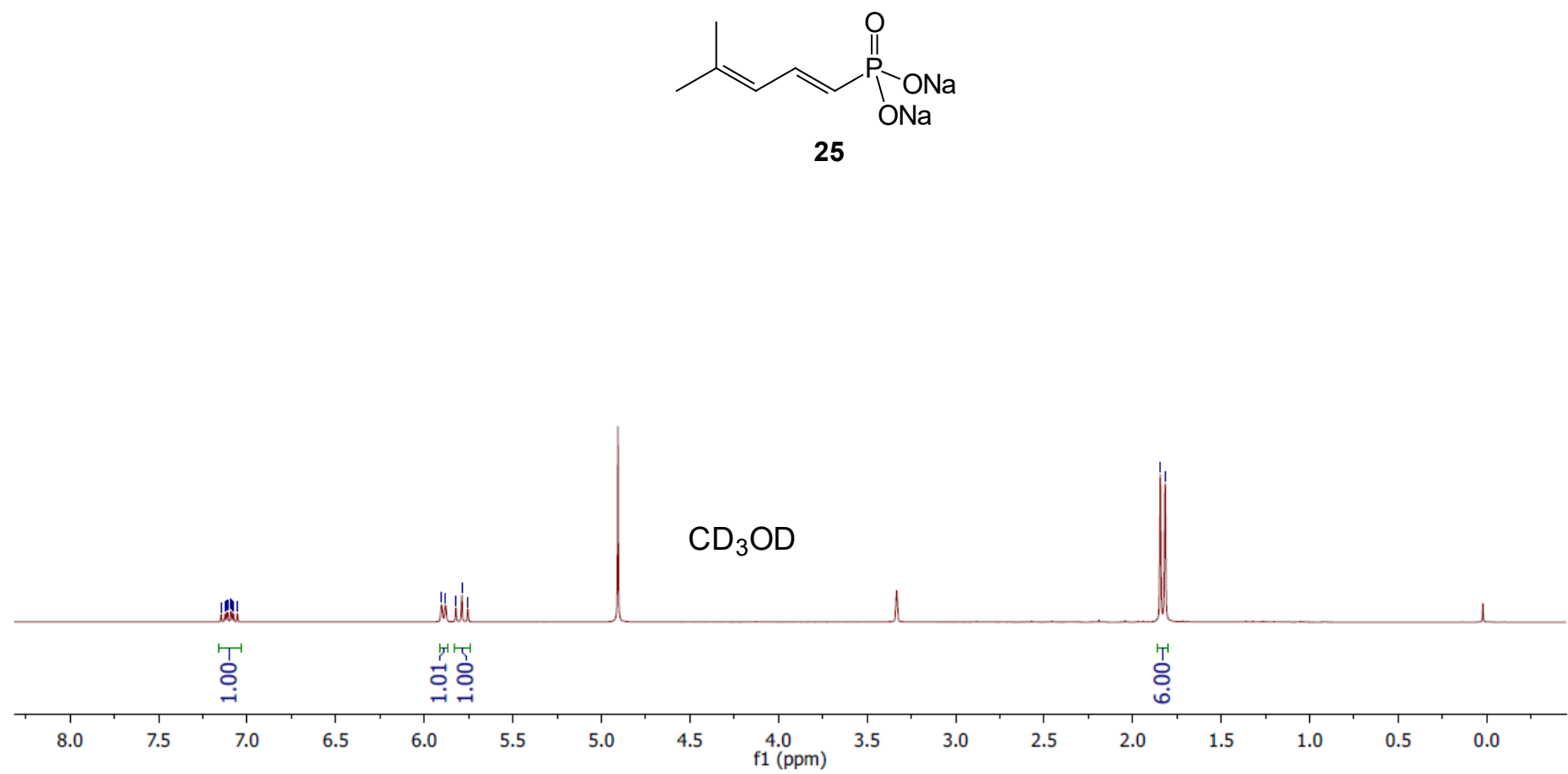
${ }^{13} \mathrm{C}$ NMR spectrum of compound 25 (126 MHz)

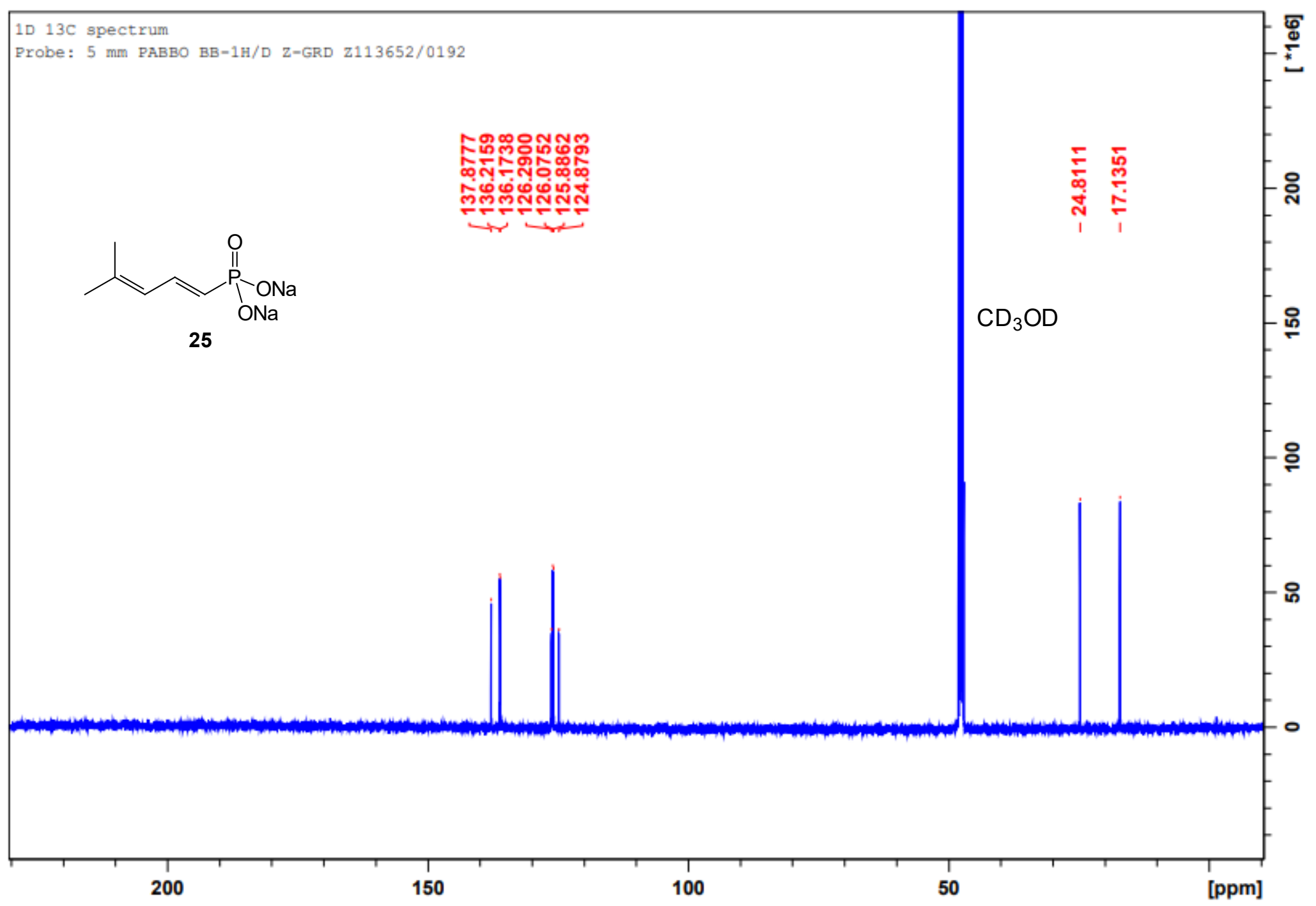


${ }^{31} \mathrm{P}$ NMR spectrum of compound 25 (202 MHz)

phorous

trum

㜽।

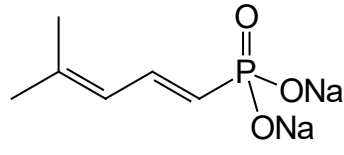

